\title{
Solid Phase Characterization of Tank 241-C-108 Residual Waste Solids Samples
}

G. A. Cooke

J. A. Pestovich

H. J. Huber

Washington River Protection Solutions LLC

Date Published

April 2013

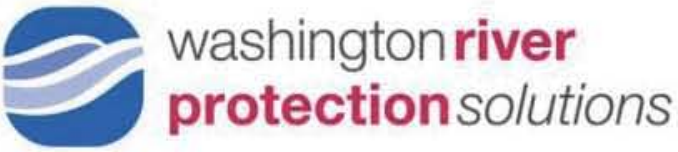

Prepared for the U.S. Department of Energy Office of River Protection

Contract No. DE-AC27-08RV14800 


\title{
LEGAL DISCLAIMER
}

\begin{abstract}
This report was prepared as an account of work sponsored by an agency of the United States Government. Neither the United States Government nor any agency thereof, nor any of their employees, makes any warranty, express or implied, or assumes any legal liability or responsibility for the accuracy, completeness, or any third party's use or the results of such use of any information, apparatus, product, or process disclosed, or represents that its use would not infringe privately owned rights. Reference herein to any specific commercial product, process, or service by trade name, trademark, manufacturer, or otherwise, does not necessarily constitute or imply its endorsement, recommendation, or favoring by the United States Government or any agency thereof or its contractors or subcontractors. The views and opinions of authors expressed herein do not necessarily state or reflect those of the United States Government or any agency thereof.
\end{abstract}

This report has been reproduced from the best available copy.

Printed in the United States of America 


\section{Table of Contents}

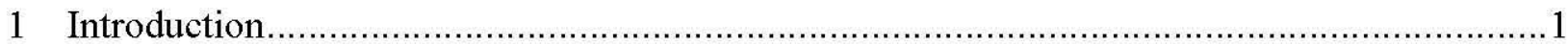

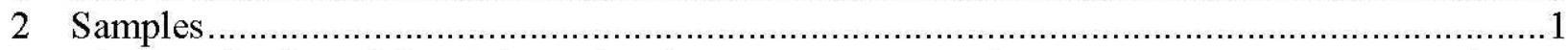

3 Characterization of the Light-Colored Coarse Fragments from 8C-12-23, 8C-12-25, and 8C$12-29$ 3

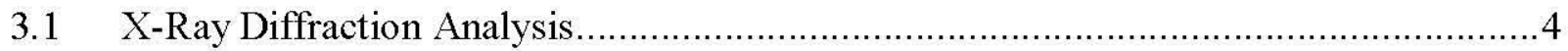

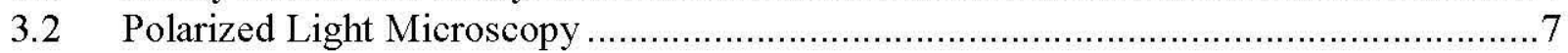

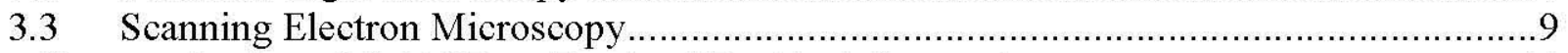

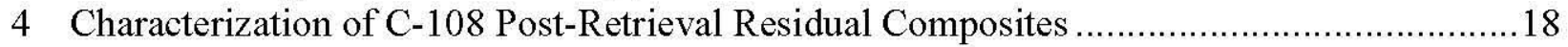

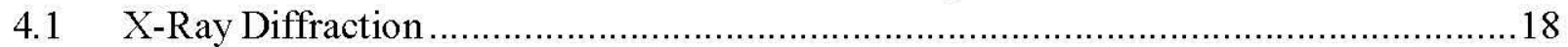

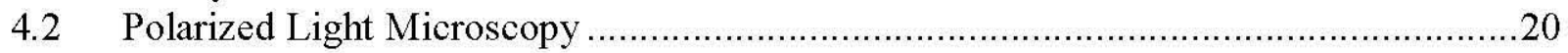

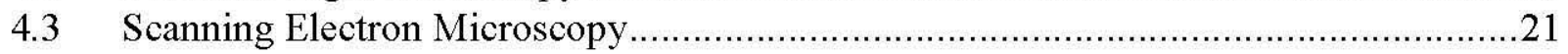

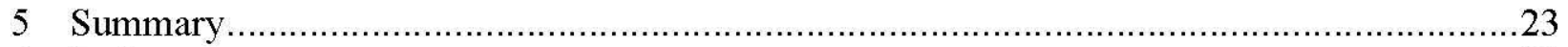

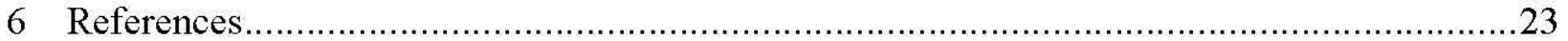

\section{List of Figures}

Figure 1. Sample Breakdown and Analysis Diagram for Tank 241-C-108 Residual Solids Solid Phase Characterization Analysis.

Figure 2. Hot Cell Photographs of Grab Samples with Large "Chunks" of Light-Colored

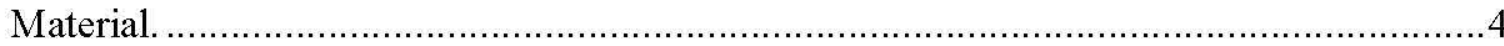

Figure 3. X-Ray Diffraction Pattern, Sample S12R000491_.................................................

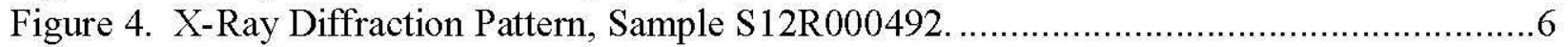

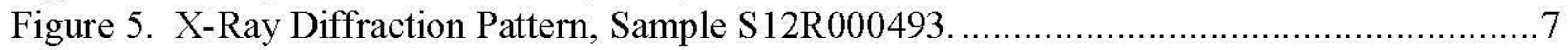

Figure 6. Polarized Light Microscopy Images of S12R000491 in 1.55 Oil, Crossed Polarizers, Red I Compensator Plate. ……........................................................................ 8

Figure 7. Polarized Light Microscopy Images of S12R000492 in 1.55 Oil, Crossed Polarizers, Red I Compensator Plate.

Figure 8. Polarized Light Microscopy Images of S12R000493 in 1.55 Oil, Crossed Polarizers, Red I Compensator Plate. ...............................................................................

Figure 9. Sample S12R000491. Field View and Energy Dispersive X-Ray Spectrometer Spectrum from Area Inside Yellow Box. ............................................................. 10

Figure 10. Sample S12R000492. Field View and Energy Dispersive X-Ray Spectrometer Spectrum from Area Inside Yellow Box. ................................................................10

Figure 11. Sample S12R000493. Field View and Energy Dispersive X-Ray Spectrometer Spectrum from Area Inside Yellow Box. ..............................................................11

Figure 12. Sample S12R000491. Secondary Electron Image of Natrophosphate Crystal (Left) with Area in Box Enlarged at Center and Energy Dispersive X-Ray Spectrometer

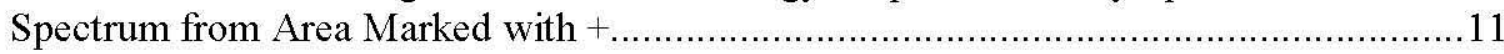

Figure 13. Sample S12R000491. Secondary Electron Image of Natrophosphate Crystal (Left) and Energy Dispersive X-Ray Spectrometer Spectrum from Area Marked with + Showing Sodium Enrichment of Coating Material. 
Figure 14. Sample S12R000491. Secondary Electron Image of Gibbsite Crystal (Left) and Energy Dispersive X-Ray Spectrometer Spectrum from Area Marked with + Showing Some Sodium Enrichment of Coating Material on Etched Crystal................................12

Figure 15. Sample S12R000491. Secondary Electron Image of Thermonatrite Crystal (Left) and Energy Dispersive X-Ray Spectrometer Spectrum from Area Marked with $+\ldots \ldots \ldots \ldots \ldots . . .13$

Figure 16. Sample S12R000492. Secondary Electron Image of Thermonatrite Crystal (Left) and Energy Dispersive X-Ray Spectrometer Spectrum from Area Marked with $+\ldots \ldots \ldots \ldots \ldots . .13$

Figure 17. Sample S12R000491. Backscatter Electron Image of Uranium-Rich Aggregate (Left) with Secondary Electron Image of Same Area (Center) and Energy Dispersive X-Ray Spectrometer Spectrum from Area Marked with + (Right) ...................................14

Figure 18. Sample S12R000491. Backscatter Electron Image of Iron-Rich Aggregate (Left) with Secondary Electron Image of Same Area (Center) and Energy Dispersive X-Ray Spectrometer Spectrum from Area Marked with + (Right).

Figure 19. Sample S12R000491. Backscatter Electron Image of Sodium-Aluminum-StrontiumRich Crystal (Upper Left) with Secondary Electron Image of Same Crystal (Upper Right) and Energy Dispersive X-Ray Spectrometer Spectra from Area Marked with +1 (lower Left) and +2 (Lower Right).

Figure 20. Sample S12R000491. Backscatter Electron Image of Sodium-Aluminum-StrontiumRich Irregular Crystal (Left) with Secondary Electron Image of Same Crystal (Center) and Energy Dispersive X-Ray Spectrometer Spectrum from Area Marked with + (Right).

Figure 21. Sample S12R000492. Secondary Electron Image of Strontium-Rich Irregular Crystal (Left) with Backscatter Electron Image of Area in Yellow Box (Middle) and Energy Dispersive X-Ray Spectrometer Spectra from Area Marked with + in the Middle Image (Right, $\mathrm{X}$ and $\mathrm{Y}$ scales of the EDS spectruim are expanded).

Figure 22. Sample S12R000492. Backscatter Electron Image of Apparent Strontium-Rich Particle (Left). Energy Dispersive X-Ray Spectrometer Spectrum (From Area Marked with + ) Could be Confused with Strontium (Center). Actual Element Responsible is

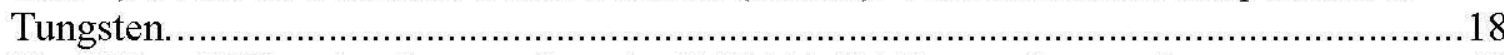

Figure 23. X-Ray Diffraction Pattern, Sample S12R000494 Brown Composite.....................19

Figure 24. X-Ray Diffraction Pattern, Sample S12R000495 Grab Sample Composite.............20 Figure 25. Polarized Light Microscopy Image of S12R000494 in 1.55 Oil, Crossed Polarizers,

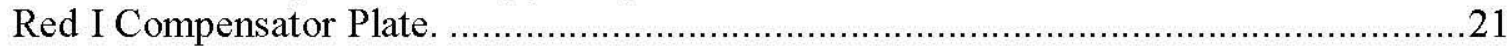

Figure 26. Polarized Light Microscopy Images of S12R000495 in 1.55 oil, Uncrossed Polarizers (Left) Crossed Polarizers, Red I Compensator Plate (Right). 21

Figure 27. Sample S12R000494. Field View and Energy Dispersive X-Ray Spectrometer

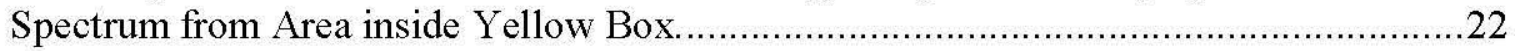

Figure 28. Sample S12R000495. Field View and Energy Dispersive X-Ray Spectrometer

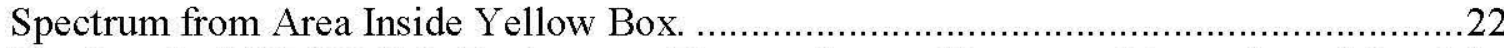

Figure 29. Sample S12R000495. Backscatter Electron Image Close up of Amorphous Material (Left) with Energy Dispersive X-Ray Spectrometer Spectrum from Area Marked with a + to the Right. 


\section{List of Tables}

Table 1. Subsamples for Solid Phase Characterization.........................................................

\section{List of Terms}

\section{Acronyms and Abbreviations}

C-108 tank 241-C-108

ATL Advanced Technologies and Laboratories International, Inc.

BEI backscatter electron image

crP $+\quad$ crossed polarizers

EDS energy dispersive X-ray spectrometer

PLM polarized light microscopy

SEI secondary electron images

SEM scanning electron microscopy or microscope

SPC solid phase characterization

uncrP uncrossed polarizers

XRD X-ray diffraction

\section{Units}

$\begin{array}{ll}\mathrm{g} & \text { gram } \\ \mu \mathrm{m} & \text { micrometer } \\ \mathrm{keV} & \text { thousand electron Volts } \\ \mathrm{deg} & \text { degree }\end{array}$




\section{INTRODUCTION}

This report presents the results for solid phase characterization (SPC) of solid samples removed from tank 241-C-108 (C-108) on August 12-13, 2012, using the off-riser sampler. The samples were collected and delivered to the 222-S Laboratory in accordance with RPP-PLAN-52471, Sampling and Analysis Plan for Residual Waste Solids in Tank 241-C-108. Samples were received at the 222-S Laboratory on August 13 and were described and photographed. The Advanced Technologies and Laboratories International, Inc. (ATL) sample breakdown was reported along with the results from chemical analysis in RPP-RPT-54006, Final Report for Tank 241-C-108 Residual Solid Samples. Directions to subsample for SPC were provided August 15, 2012, in 12-CCN-18, Item \#2, Appendix A. Subsampling was performed by ATL personnel in the 11A hot cells; SPC was performed by WRPS personnel.

The SPC analyses that were performed include scanning electron microscopy (SEM) using the ASPEX ${ }^{1}{ }^{1}$ scanning electron microscope, X-ray diffraction (XRD) using the Rigaku ${ }^{2}$ MiniFlex X-ray diffractometer, and polarized light microscopy (PLM) using the Nikon ${ }^{3}{ }^{3}$ Eclipse Pol optical microscope. The SEM is equipped with an energy dispersive X-ray spectrometer (EDS) to provide chemical information. Gary A. Cooke conducted the SEM analysis, John A. Pestovich performed the XRD analysis, and Dr. Heinz J. Huber performed the PLM examination. The results of these analyses are presented here.

Samples were prepared for XRD, SEM, and PLM analyses using standard procedures ATS-LT-507-101, "222-S Laboratory X-Ray Diffractometry (XRD)," ATS- LT-161-100, "222-S Laboratory Sample Preparation and Operating Procedure for Scanning Electron Microscopes," and ATS-LT-519-107, "222-S Laboratory Polarized Light Microscopy," respectively.

\section{SAMPLES}

As directed in 12-CCN-18, ATL personnel prepared five subsamples for SPC (see Table 1) as follows:

- Approximately $1 \mathrm{~g}$ of the gray/white coarse fragments or gray material from each of jars $8 \mathrm{C}-12-23,-25$, and -29 was collected. These three subsamples were placed in separate jars.

- Subsamples of approximately $0.5 \mathrm{~g}$ of brown material from each of jars $8 \mathrm{C}-12-21,-27$, and -28 were combined in a single jar.

\footnotetext{
${ }^{1}$ ASPEX is a registered trademark of ASPEX Corporation, Delmont, Pennsylvania.

${ }^{2}$ Rigaku is a registered trademark of Rigaku Americas Corporation, The Woodlands, Texas.

${ }^{3}$ Nikon is a registered trademark of Nikon Corporation, Tokyo, Japan.
} 
- One subsample (approximately $0.5 \mathrm{~g}$ ) of material from composites A, B, and C after completion of homogenization was placed in a single jar.

Figure 1 presents the sample breakdown and analysis diagram prepared to detail the sampling that was performed.

Table 1. Subsamples for Solid Phase Characterization.

\begin{tabular}{|l|c|c|c|}
\hline \multicolumn{1}{|c|}{ Client ID } & Laboratory ID(s) & Date Subsampled & Comments \\
\hline 8C-12-23 Light Colored Chunk & S12T017692 & $08-20-2012$ & $1.3 \mathrm{~g}$ net \\
& S12R000491 & & \\
\hline 8C-12-25 Light Colored Chunk & S12T017693 & $08-20-2012$ & $1.0 \mathrm{~g}$ net \\
& S12R000492 & & \\
\hline 8C-12-29 Light Colored Chunk & S12T017694 & $08-20-2012$ & $0.8 \mathrm{~g}$ net \\
& S12R000493 & & \\
\hline 8C-12-21 Brown Material & S12T017793 & $08-20-2012$ & $1.6 \mathrm{~g}$ net \\
8C-12-27 Brown Material & S12R000494 & & $1.4 \mathrm{~g}$ net \\
8C-12-28 Brown Material & & & $3.9 \mathrm{~g}$ total \\
\hline 8C-12-21, 22, 23 (Composite A) & S12T017736 & $10-02-2012$ & $2.6 \mathrm{~g}$ net \\
8C-12-25, 26, 27 (Composite B) & S12R000495 & & \\
8C-12-24, 28, 29 (Composite C) & & & \\
\hline
\end{tabular}


Figure 1. Sample Breakdown and Analysis Diagram for Tank 241-C-108 Residual Solids Solid Phase Characterization Analysis.

Customer: Research

C108 CLO2 SPC

TSCA Regulated for PCB

Riser 6

Group 20121343

Due: $10 / 31 / 2012$
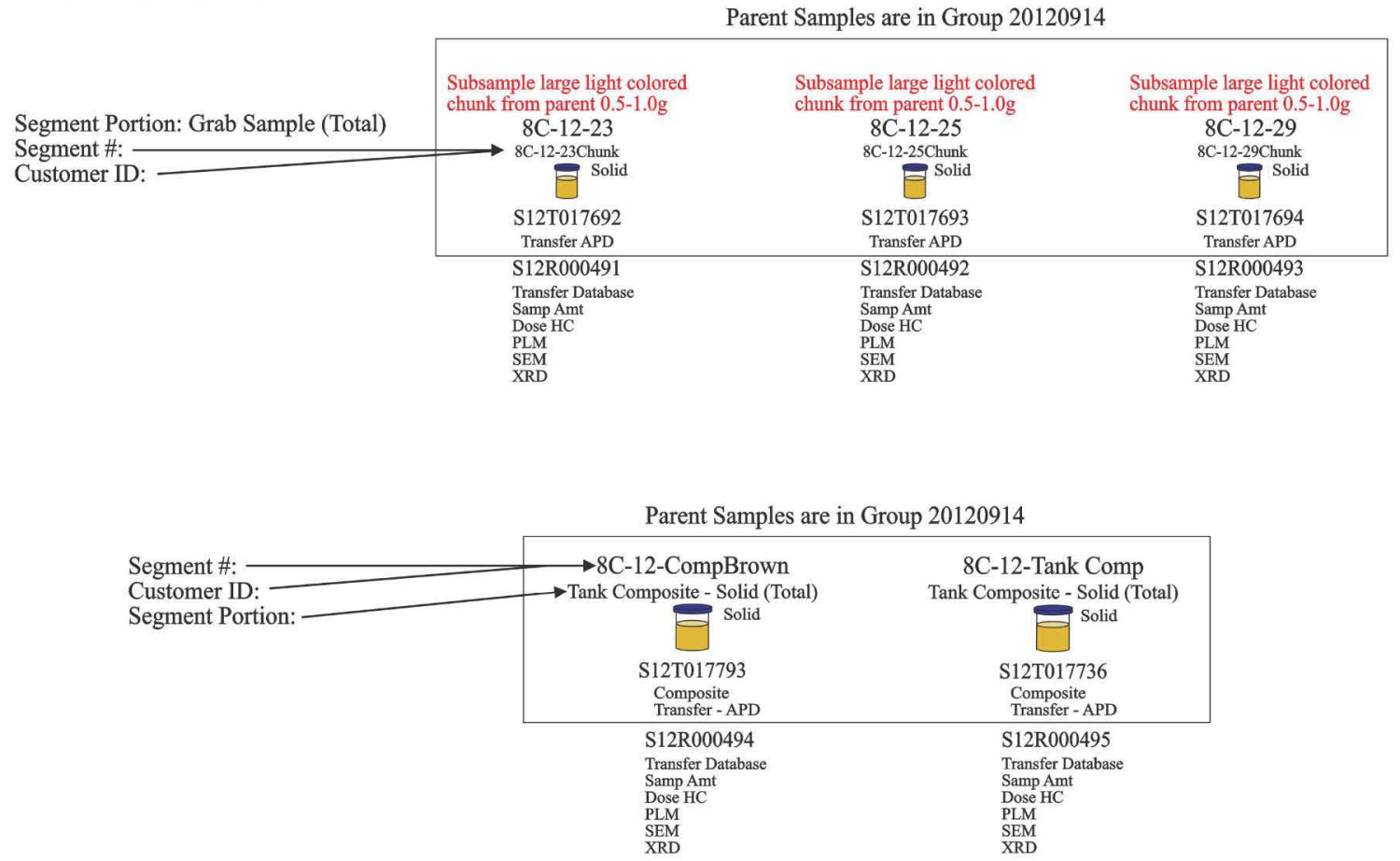

Composite of $8 \mathrm{C}-12-21,-27$, and 28

Composite of 8C-12-Comp A, Comp B, and Comp C

\section{CHARACTERIZATION OF THE LIGHT-COLORED COARSE FRAGMENTS FROM 8C-12-23, 8C-12-25, AND 8C-12-29}

All three chunk samples consisted of fine-grained aggregate. The color was dominantly white with red and brown mottling. Samples S12R000491 and 492 were slightly moist, sample S12R000493 was dry. The aggregates crushed easily. Once crushed and dried, the samples consisted of homogeneous light tan to brown fine solids. 
Figure 2. Hot Cell Photographs of Grab Samples with Large "Chunks" of Light-Colored Material.

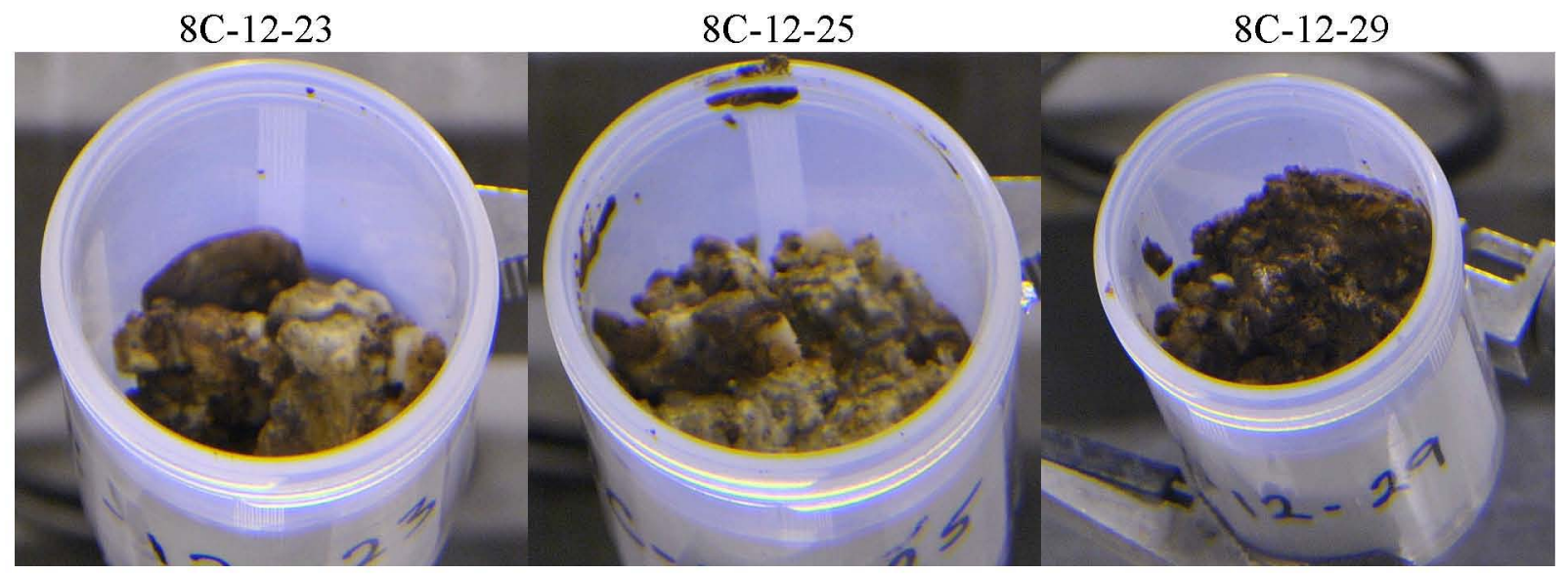

\subsection{X-RAY DIFFRACTION ANALYSIS}

Samples S12R000491, S12R000492, and S12R000493 appear to be similar in crystalline composition and concentration, except that natrophosphate $\left[\mathrm{Na}_{7} \mathrm{~F}\left(\mathrm{PO}_{4}\right)_{2} \bullet 19 \mathrm{H}_{2} \mathrm{O}\right]$ was not identified as a minor phase in sample S12R000491. The sample compositions reported below are relative amounts based upon all the crystalline species present in each individual sample. Refer to laboratory notebook HNF-N-105-1, "Rigaku® MiniFlex X-Ray Diffractometer," pages 121-123 for test information and specifics on each individual sample.

S12R000491 (8C-12-23 Chunk). Sample S12R000491 (8C-12-23 Chunk) appeared to be a moist white-red-brown aggregate, and once prepared/dried appeared to be homogeneous light brown fine solids. The major phases of the sample were identified by XRD as gibbsite $\left[\mathrm{Al}(\mathrm{OH})_{3}\right]$ and thermonatrite $\left[\mathrm{Na}_{2} \mathrm{CO}_{3} \cdot \mathrm{H}_{2} \mathrm{O}\right]$.

Chemical Name

Aluminum Hydroxide

Sodium Carbonate Monohydrate
Mineral Name

Gibbsite

Thermonatrite $\frac{\text { Formula }}{\mathrm{AI}(\mathrm{OH})_{3}}$

$\mathbf{A l}(\mathbf{O H})_{3}$

$\mathrm{Na}_{2} \mathrm{CO}_{3} \cdot \mathrm{H}_{2} \mathrm{O}$ $\sim$ Rel. Amount

Major

Major 
Figure 3. X-Ray Diffraction Pattern, Sample S12R000491.

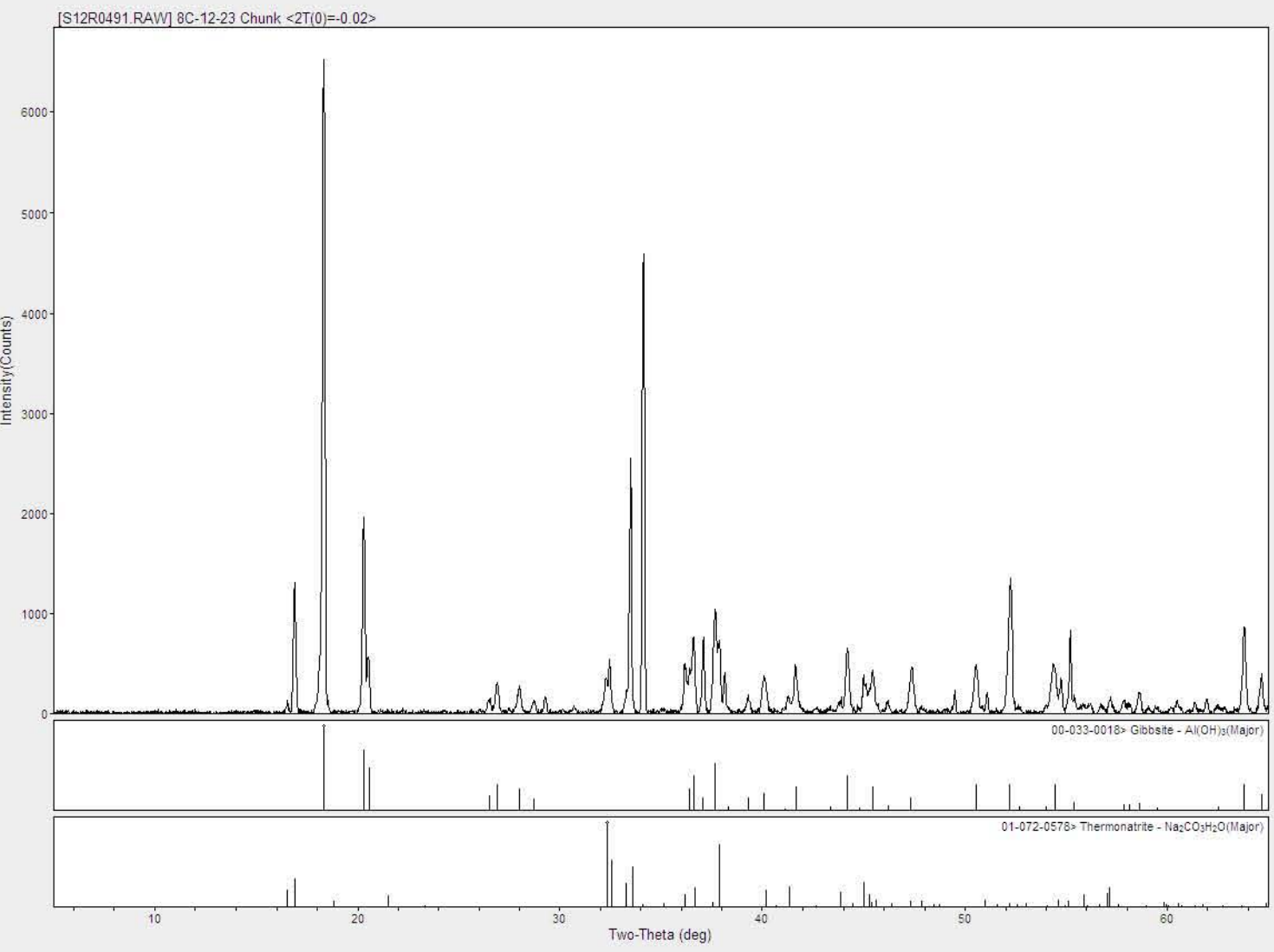

S12R000492 (8C-12-25 Chunk). Sample S12R000492 (8C-12-25 Chunk) appeared to be a moist white-red-brown aggregate and once prepared/dried appeared to be homogeneous light brown fine solids. The major phases of the sample were identified by XRD as gibbsite $\left[\mathrm{Al}(\mathrm{OH})_{3}\right]$ and thermonatrite $\left[\mathrm{Na}_{2} \mathrm{CO}_{3} \bullet \mathrm{H}_{2} \mathrm{O}\right]$. Natrophosphate $\left[\mathrm{Na}_{7} \mathrm{~F}\left(\mathrm{PO}_{4}\right)_{2} \bullet 19 \mathrm{H}_{2} \mathrm{O}\right]$ was identified as a minor phase.

Chemical Name

Aluminum Hydroxide

Sodium Carbonate Monohydrate

Sodium Fluoride Phosphate Hydrate
Mineral Name

Gibbsite

Thermonatrite

Natrophosphate
Formula

$\mathrm{Al}(\mathrm{OH})_{3}$

$\mathrm{Na}_{2} \mathrm{CO}_{3} \cdot \mathrm{H}_{2} \mathrm{O}$

$\mathrm{Na}_{7} \mathrm{~F}\left(\mathrm{PO}_{4}\right)_{2} \cdot 19 \mathrm{H}_{2} \mathrm{O}$ $\sim$ Rel. Amount

Major

Major

Minor 
Figure 4. X-Ray Diffraction Pattern, Sample S12R000492.

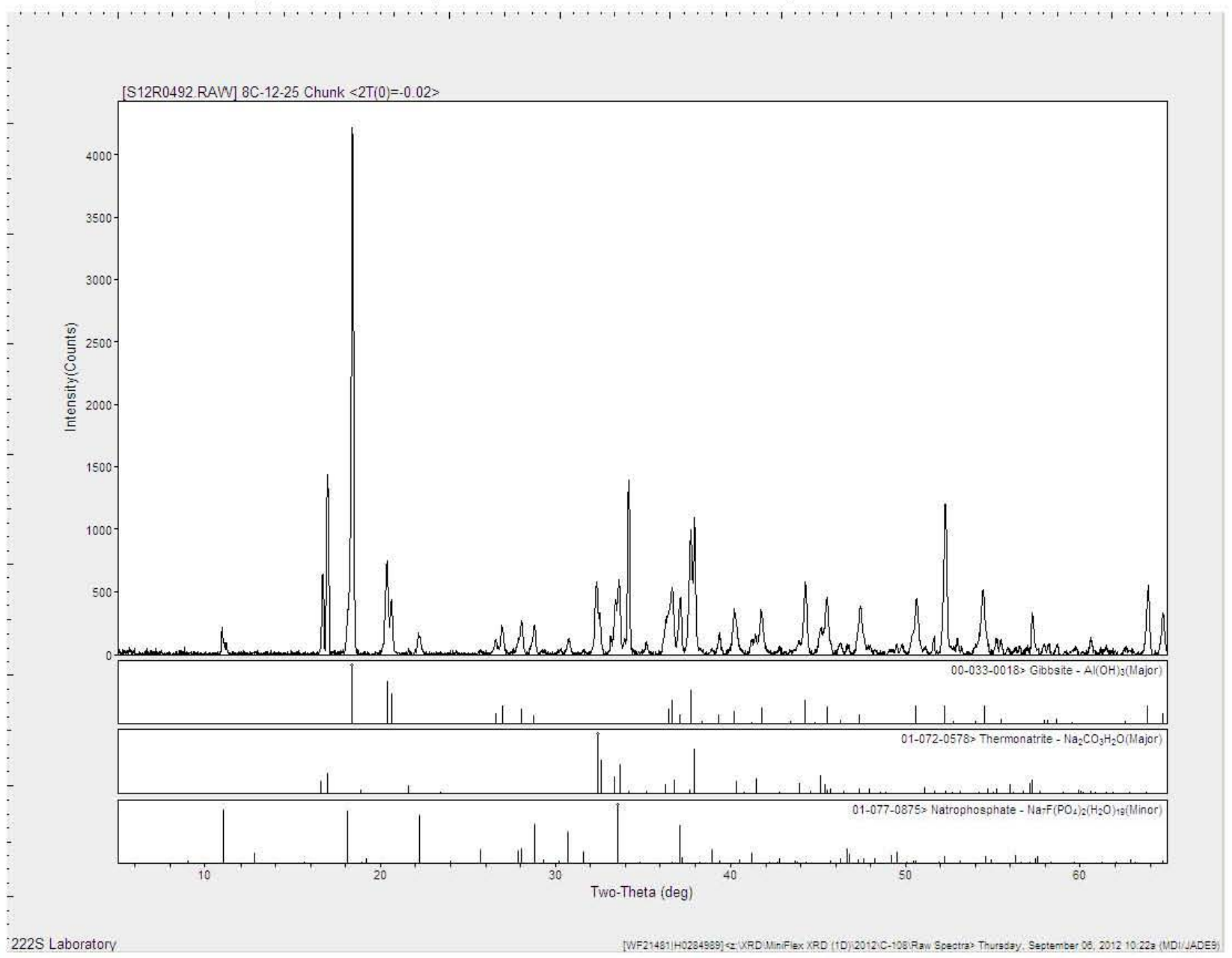

S12R000493 (8C-12-29 Chunk). Sample S12R000493 (8C-12-29 Chunk) appeared to be a dry, primarily white with red-brown aggregate, and once prepared/dried appeared to be homogeneous light tan fine solids. The major phases of the sample were identified by XRD as gibbsite $\left[\mathrm{Al}(\mathrm{OH})_{3}\right]$ and thermonatrite $\left[\mathrm{Na}_{2} \mathrm{CO}_{3} \cdot \mathrm{H}_{2} \mathrm{O}\right]$. Natrophosphate $\left[\mathrm{Na}{ }_{7} \mathrm{~F}\left(\mathrm{PO}_{4}\right)_{2} \bullet 19 \mathrm{H}_{2} \mathrm{O}\right]$ was identified as a minor phase.

Chemical Name

Aluminum Hydroxide

Sodium Carbonate Monohydrate

Sodium Fluoride Phosphate Hydrate
Mineral Name

Gibbsite

Thermonatrite

Natrophosphate
Formula

$\overline{\mathrm{Al}(\mathrm{OH})_{3}}$

$\mathrm{Na}_{2} \mathrm{CO}_{3} \cdot \mathrm{H}_{2} \mathrm{O}$

$\mathrm{Na}_{7} \mathrm{~F}\left(\mathrm{PO}_{4}\right)_{2} \bullet 19 \mathrm{H}_{2} \mathrm{O}$ $\sim$ Rel. Amount

Major

Major

Minor 
Figure 5. X-Ray Diffraction Pattern, Sample S12R000493.

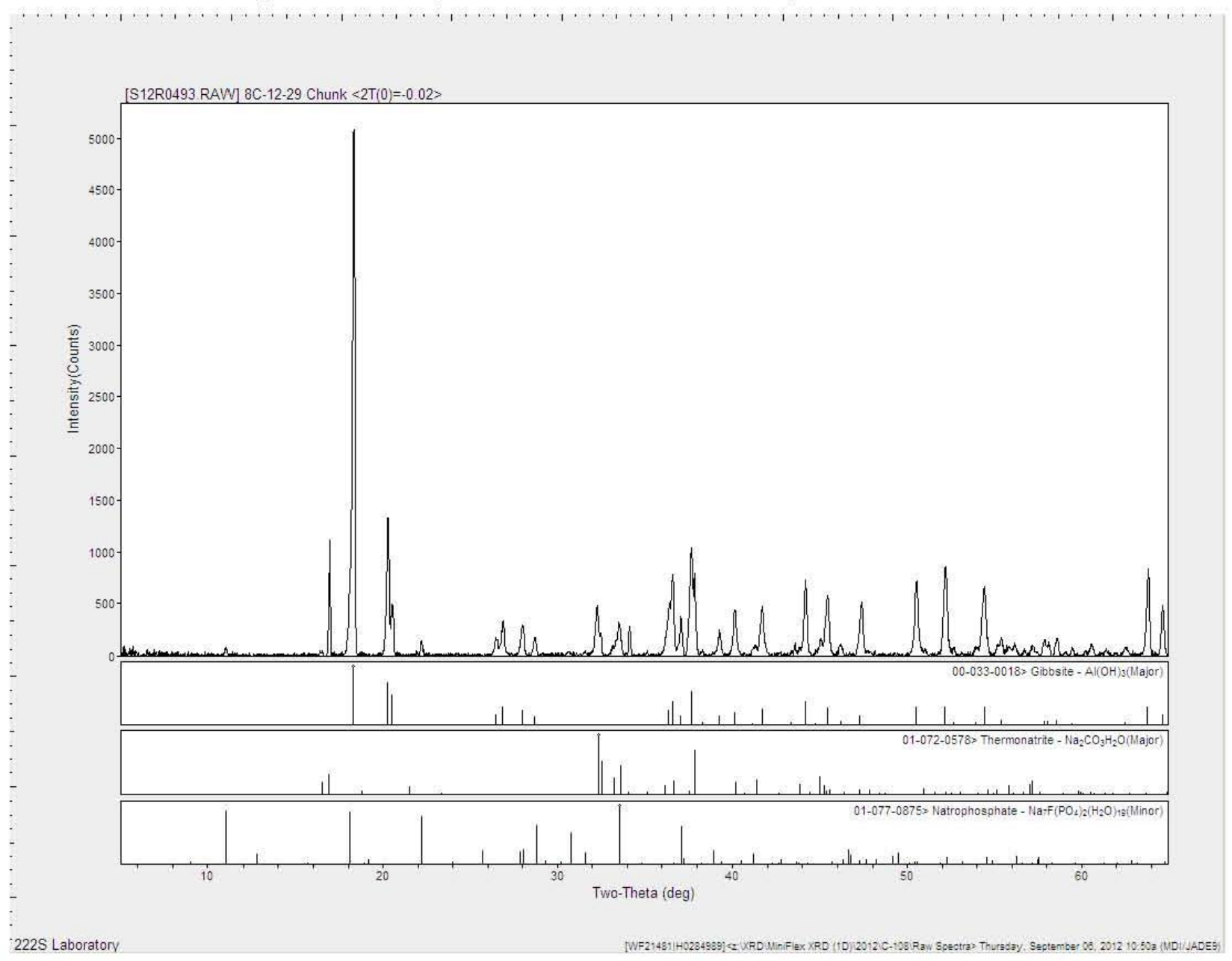

\subsection{POLARIZED LIGHT MICROSCOPY}

The three "chunk" samples were examined by PLM on November 15, 2012. All three were mounted in 1.55 refractive index oil. Refer to laboratory notebook HNF-N-395-1, "Polarized Light Microscopy Sample Log," pages 113-114, for test information and specifics on each individual sample.

Sample S12R000491 (C-108, 8C-12-23 Chunk). This sample consisted primarily of laths or blades of thermonatrite (Figure 6) as well as small needles, some of which may be natroxalate $\left[\mathrm{Na}_{2} \mathrm{C}_{2} \mathrm{O}_{4}\right]$ (Figure 6).

Some amber-colored and opaque particles were also observed. Small fragments of gibbsite were visible on portions of the slide. 
Figure 6. Polarized Light Microscopy Images of S12R000491 in 1.55 Oil, Crossed Polarizers, Red I Compensator Plate.
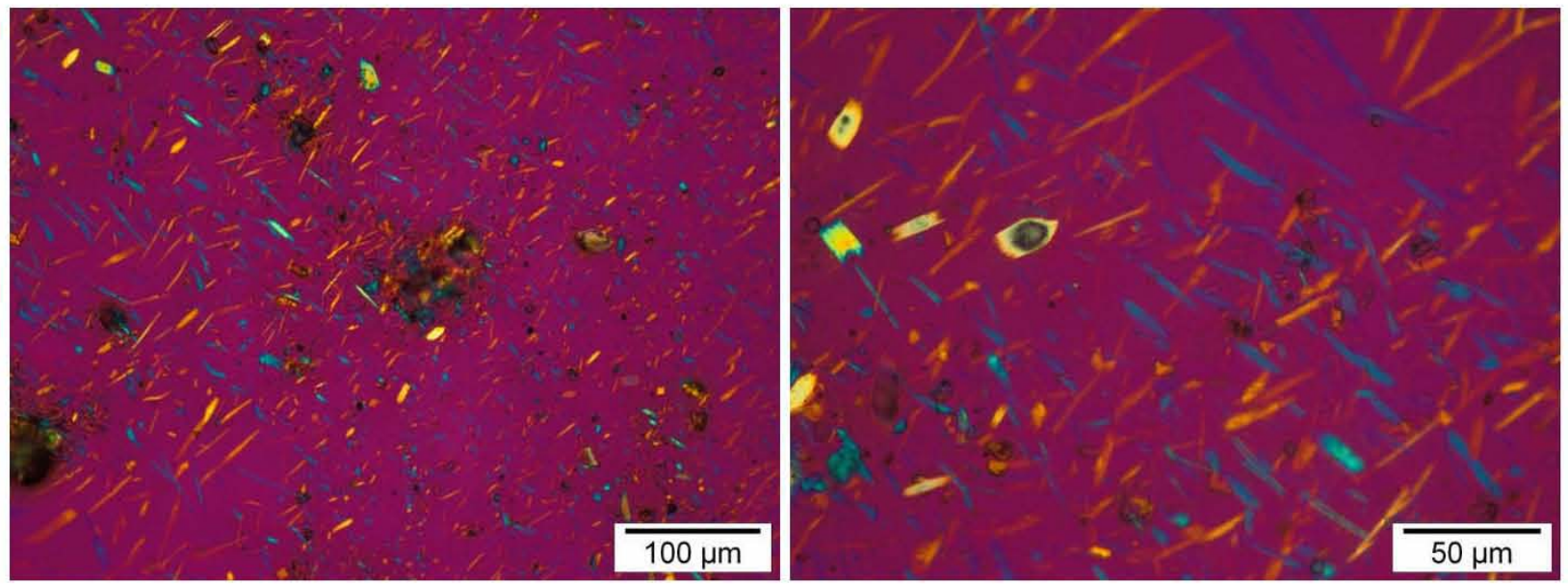

Sample S12R000492 (8C-12-25 Chunk). Sample S12R000492 appeared identical to S12R000491. Left image (Figure 7) shows sodium carbonate laths, right image shows small sodium carbonate or natroxalate needles.

Figure 7. Polarized Light Microscopy Images of S12R000492 in 1.55 Oil, Crossed Polarizers, Red I Compensator Plate.
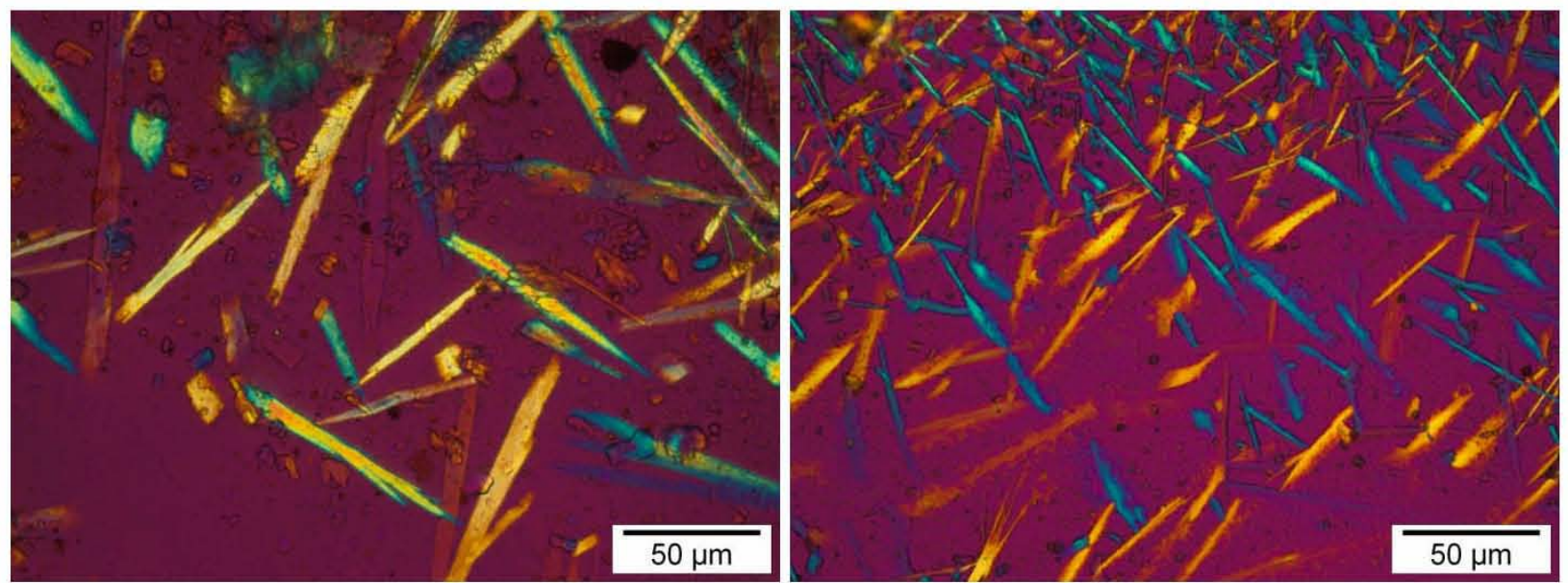
Sample S12R000493 (11/15/2012). This sample contains mostly fragmented pieces of sodium carbonate and gibbsite. In contrast to the other two samples, the amount of needle shaped crystals is greatly reduced (see Figure 8).

\section{Figure 8. Polarized Light Microscopy Images of S12R000493 in 1.55 Oil, Crossed Polarizers, Red I Compensator Plate.}
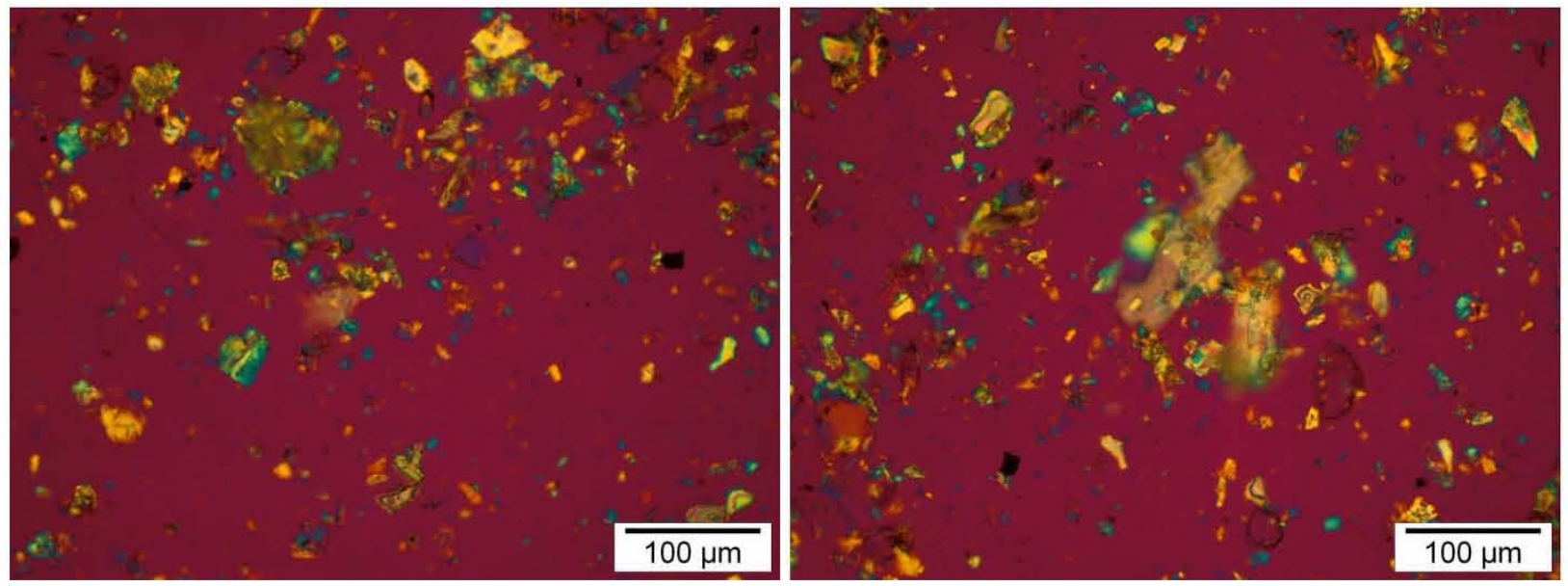

\subsection{SCANNING ELECTRON MICROSCOPY}

Examination of the chunks on the SEM confirmed the dominance of gibbsite, thermonatrite, and natrophosphate. Test information and specifics on each individual sample are found in HNF-N-832-1, "PSEM Instrument Notebook," pages 177-178. Figures 9 through 11 are low magnification secondary electron image (SEI) micrographs of Samples S12R000491, S12R000492, and S12R000493, respectively. The EDS spectrum was acquired in raster mode from the area outlined in yellow on the corresponding image.

One should note that sodium, aluminum, oxygen, and carbon dominate the EDS spectrum intensities. The lower intensity of the phosphorous peak and the lack of a discrete fluoride peak suggest that the natrophosphate is a minor component of these samples, as indicated by the XRD results. Iron, nickel, silicon, and uranium peaks are also observed on all three samples. Calcium and bismuth are occasional trace peaks. Most of the SEM images below come from Sample S12R000491 because more time was spent examining that sample. The other samples had similar appearance and distribution of phases, except where noted below. 
Figure 9. Sample S12R000491. Field View and Energy Dispersive X-Ray Spectrometer Spectrum from Area Inside Yellow Box.
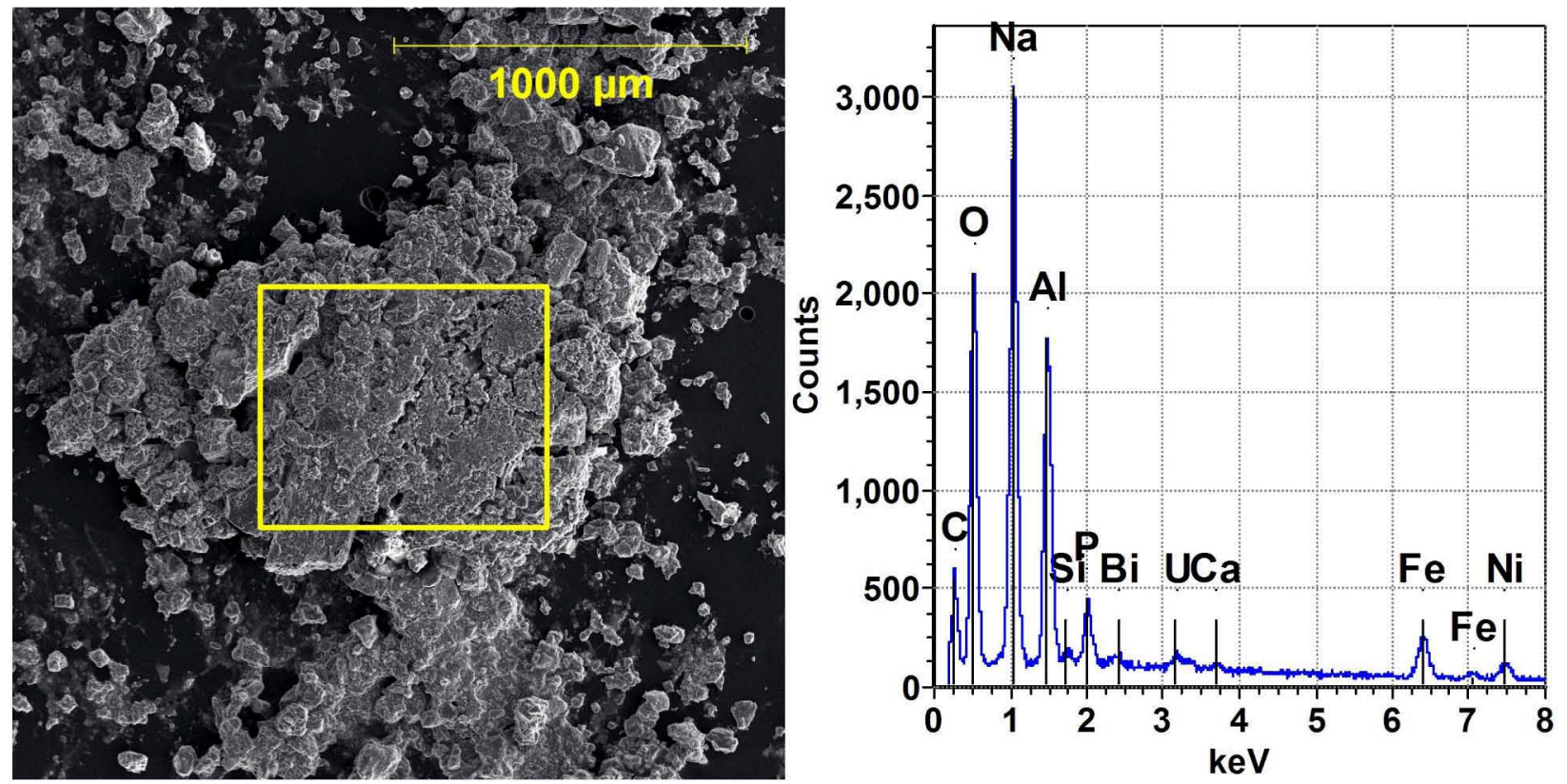

Figure 10. Sample S12R000492. Field View and Energy Dispersive X-Ray Spectrometer Spectrum from Area Inside Yellow Box.
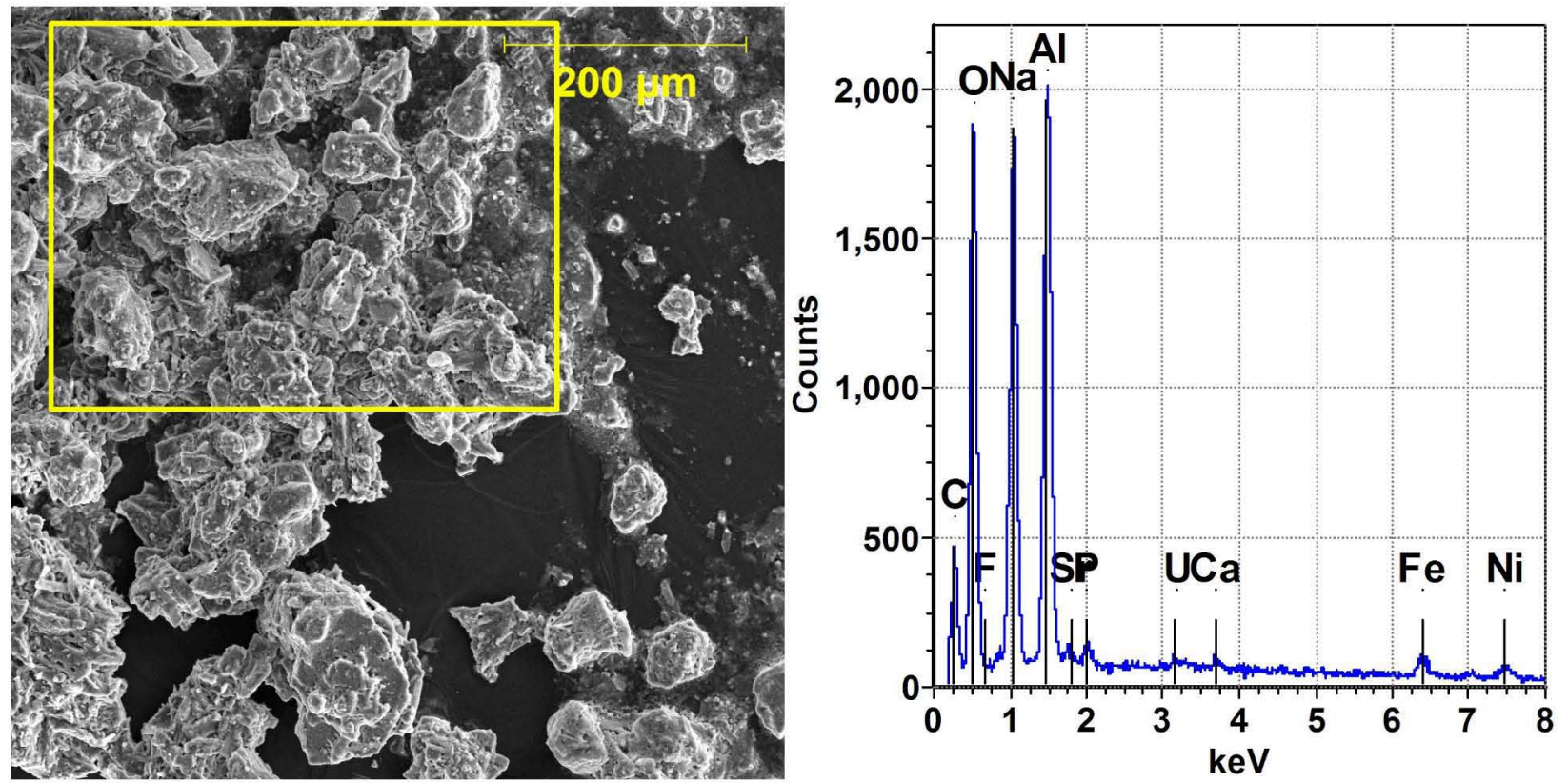
Figure 11. Sample S12R000493. Field View and Energy Dispersive X-Ray Spectrometer Spectrum from Area Inside Yellow Box.
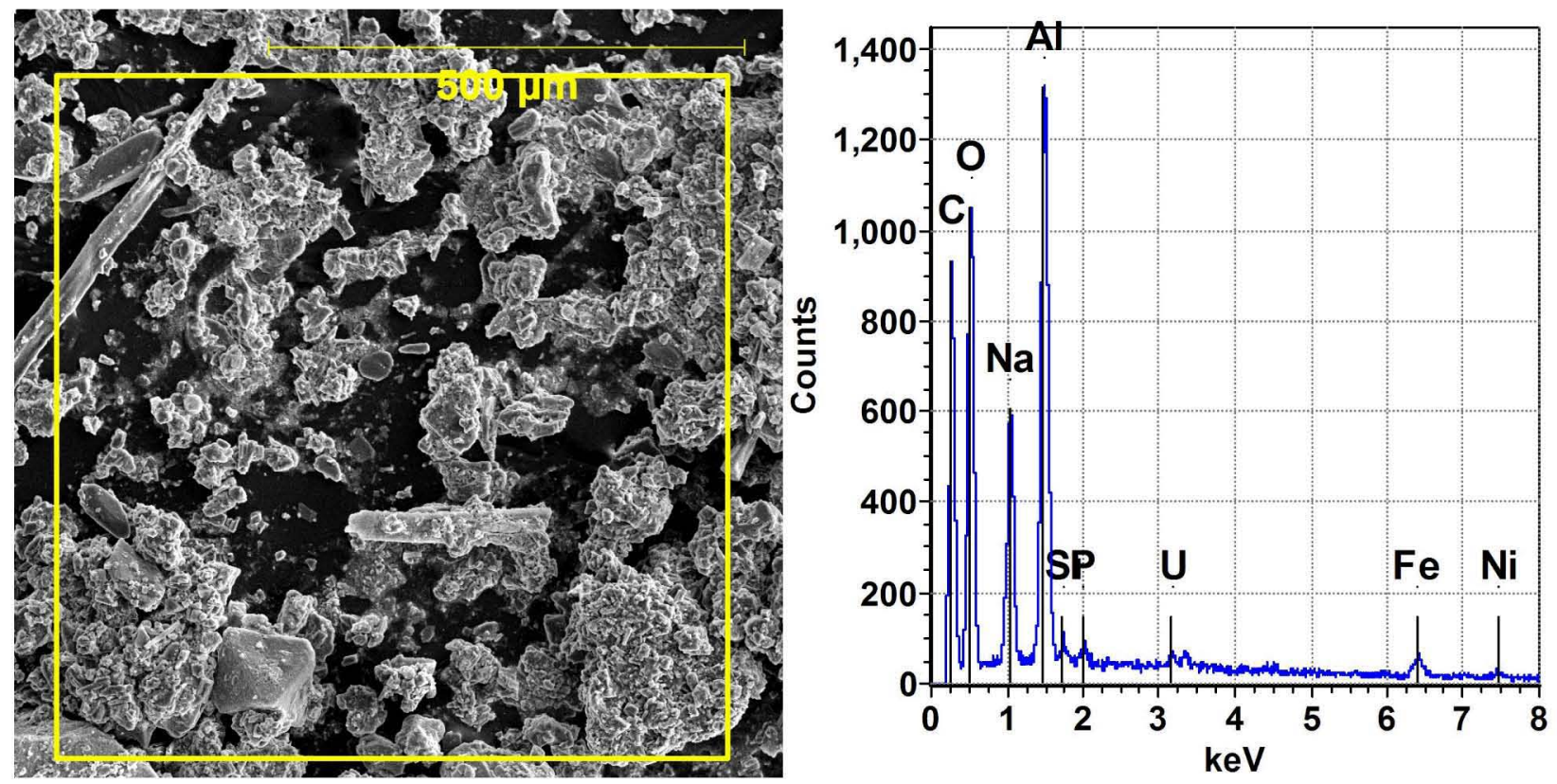

When located, the natrophosphate consists of large, irregular masses that have lost most of their crystal habit (Figure 12). They are often found with coatings of thermonatrite and/or gibbsite (Figure 13).

Figure 12. Sample S12R000491. Secondary Electron Image of Natrophosphate Crystal (Left) with Area in Box Enlarged at Center and Energy Dispersive X-Ray Spectrometer Spectrum from Area Marked with +.
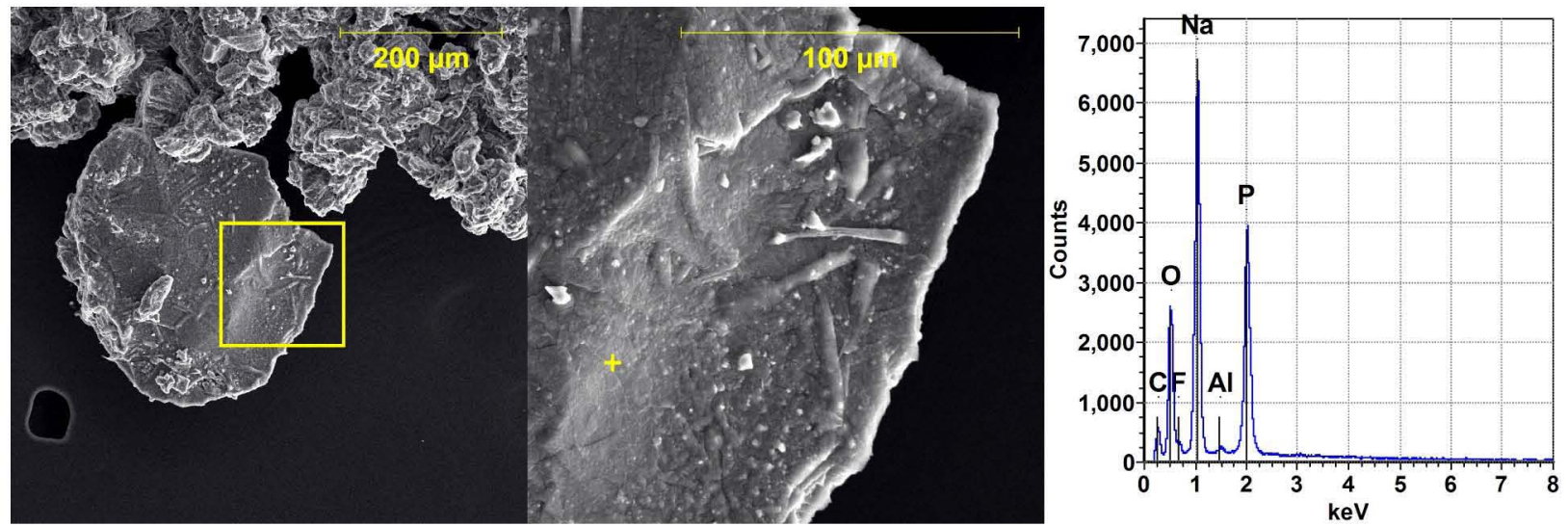
Figure 13. Sample S12R000491. Secondary Electron Image of Natrophosphate Crystal (Left) and Energy Dispersive X-Ray Spectrometer Spectrum from Area Marked with + Showing Sodium Enrichment of Coating Material.
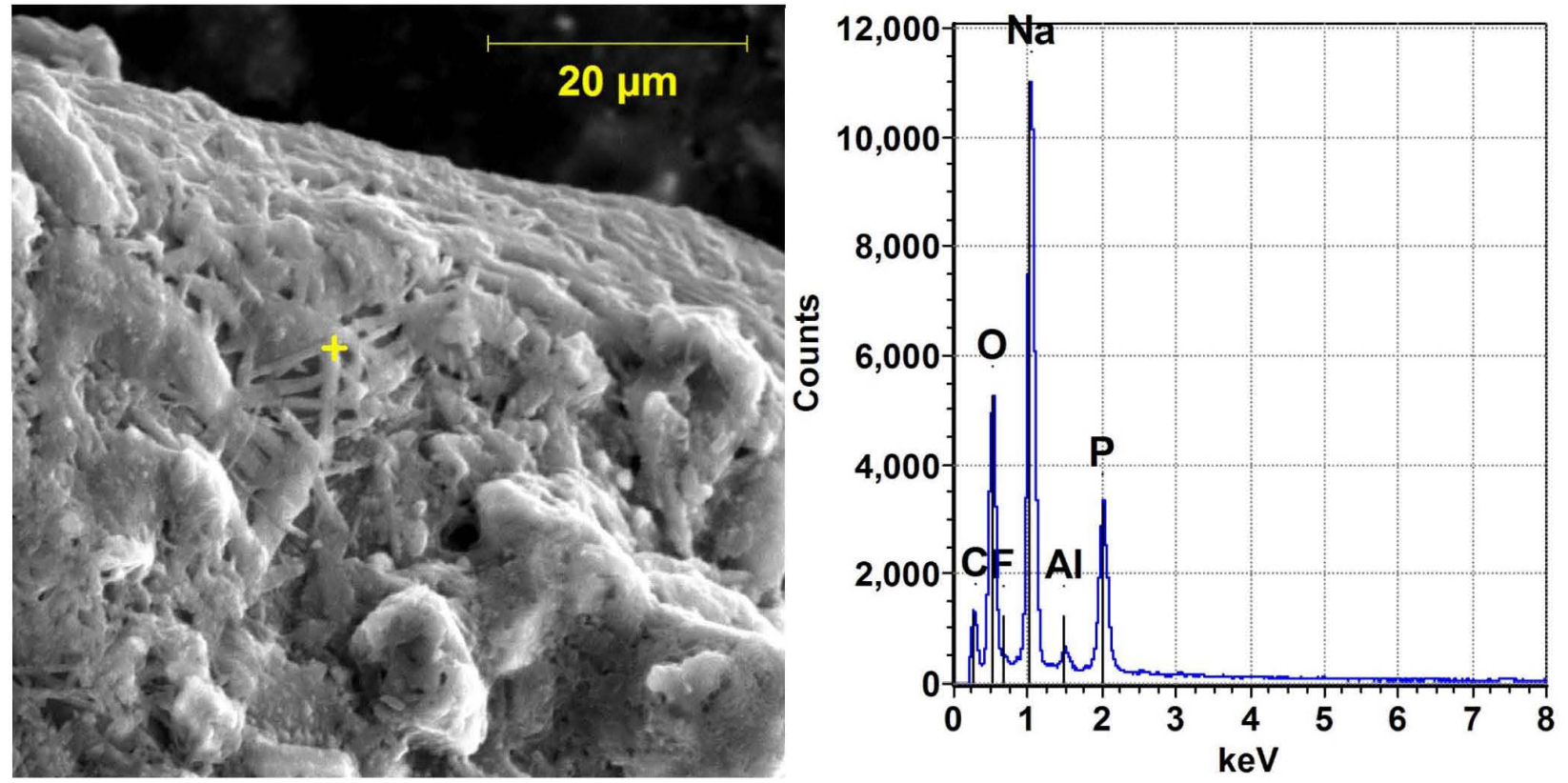

The aluminum-rich particulate (gibbsite) also showed a more irregular morphology than is usually encountered in Hanford tank waste. Pitting and etching (Figure 14) seemed to be more common than coatings. Gibbsite particles were often subhedral to anhedral.

Figure 14. Sample S12R000491. Secondary Electron Image of Gibbsite Crystal (Left) and Energy Dispersive X-Ray Spectrometer Spectrum from Area Marked with + Showing Some Sodium Enrichment of Coating Material on Etched Crystal.
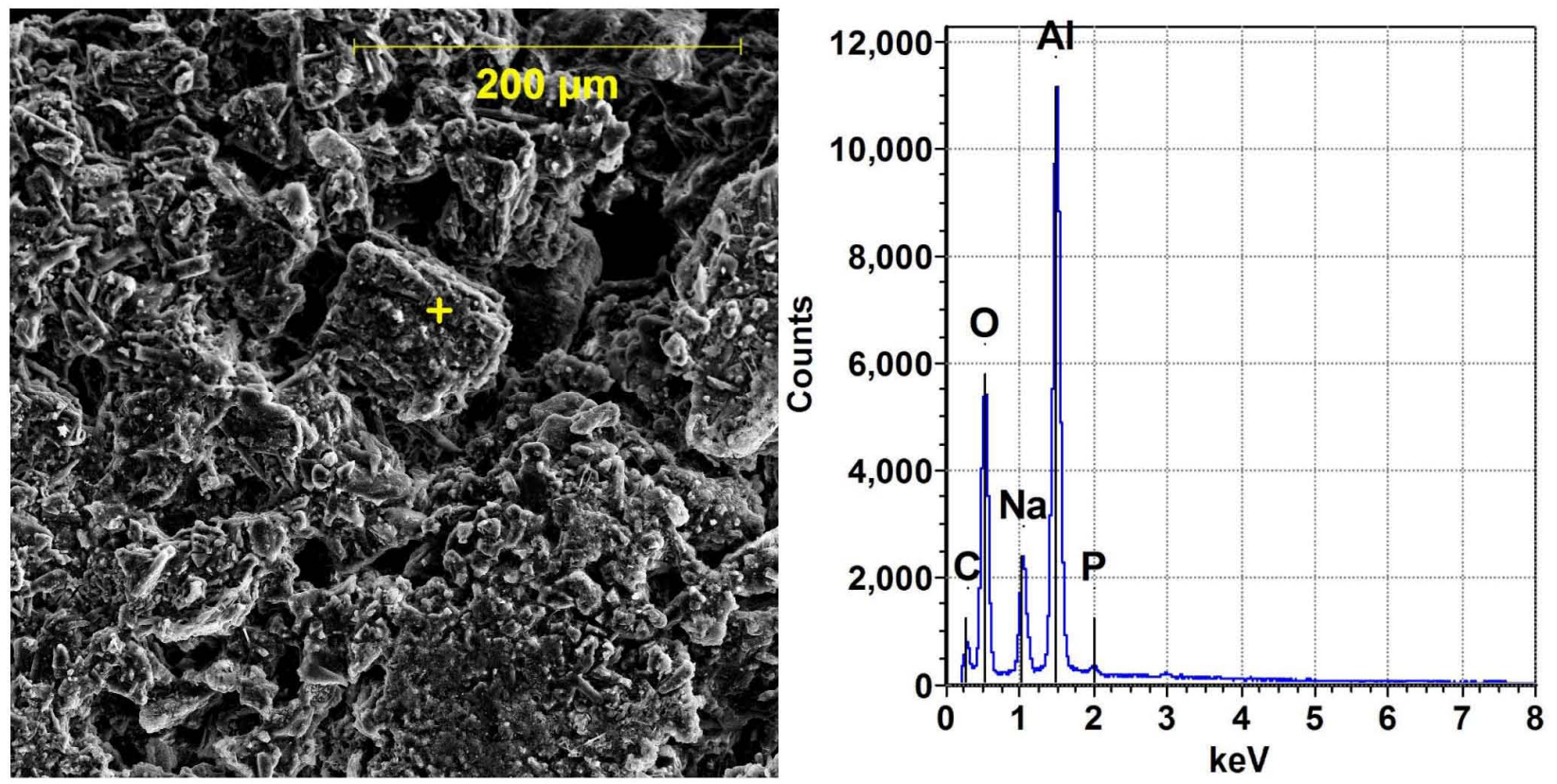
The thermonatrite produced the largest crystals, and they were often euhedral to subhedral (Figures 15 and 16). No evidence for dissolution could be seen. This suggests that the thermonatrite is in equilibrium with any liquid that was retrieved with the sample.

Figure 15. Sample S12R000491. Secondary Electron Image of Thermonatrite Crystal (Left) and Energy Dispersive X-Ray Spectrometer Spectrum from Area Marked with +.
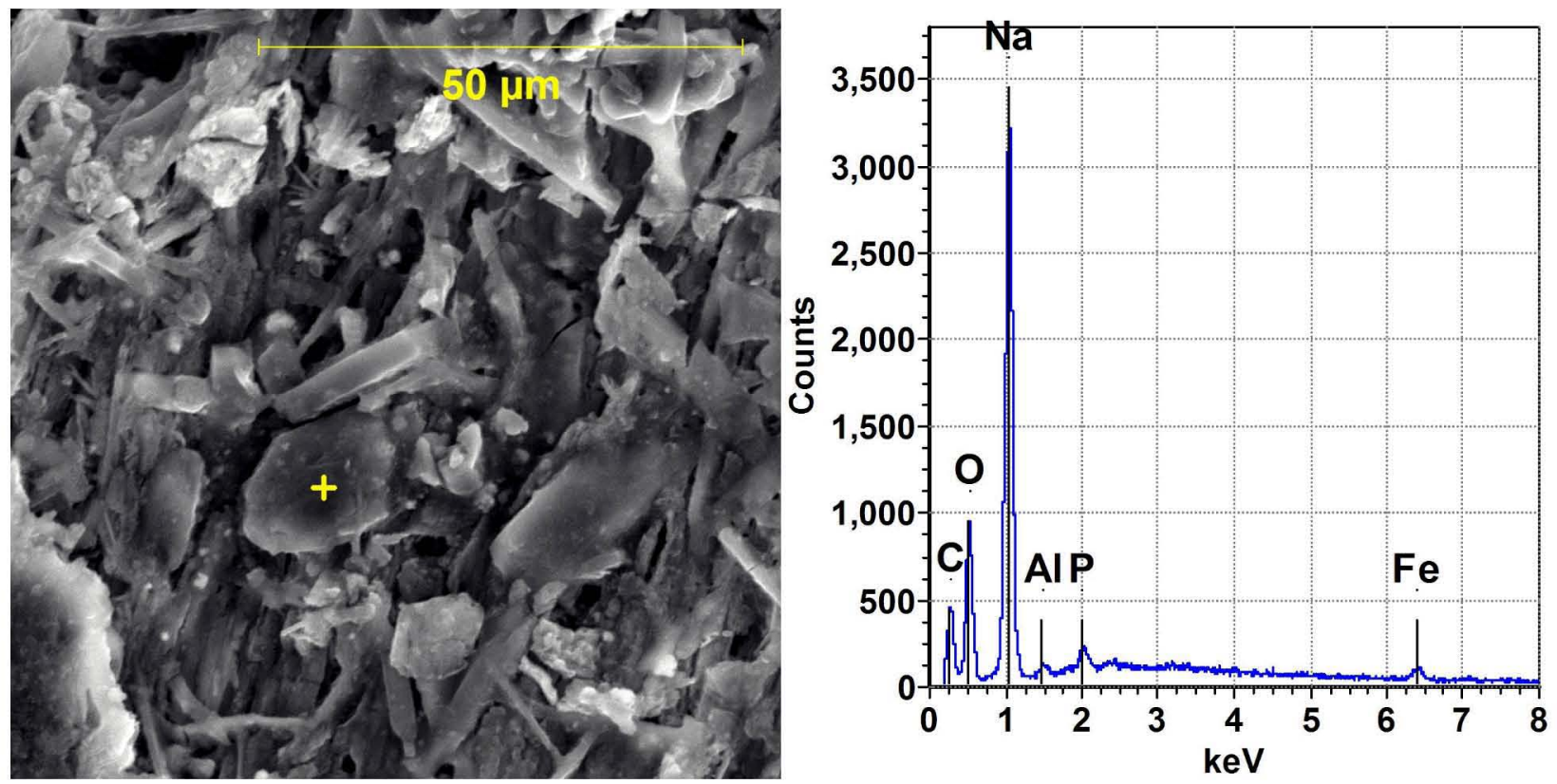

Figure 16. Sample S12R000492. Secondary Electron Image of Thermonatrite Crystal (Left) and Energy Dispersive X-Ray Spectrometer Spectrum from Area Marked with +.
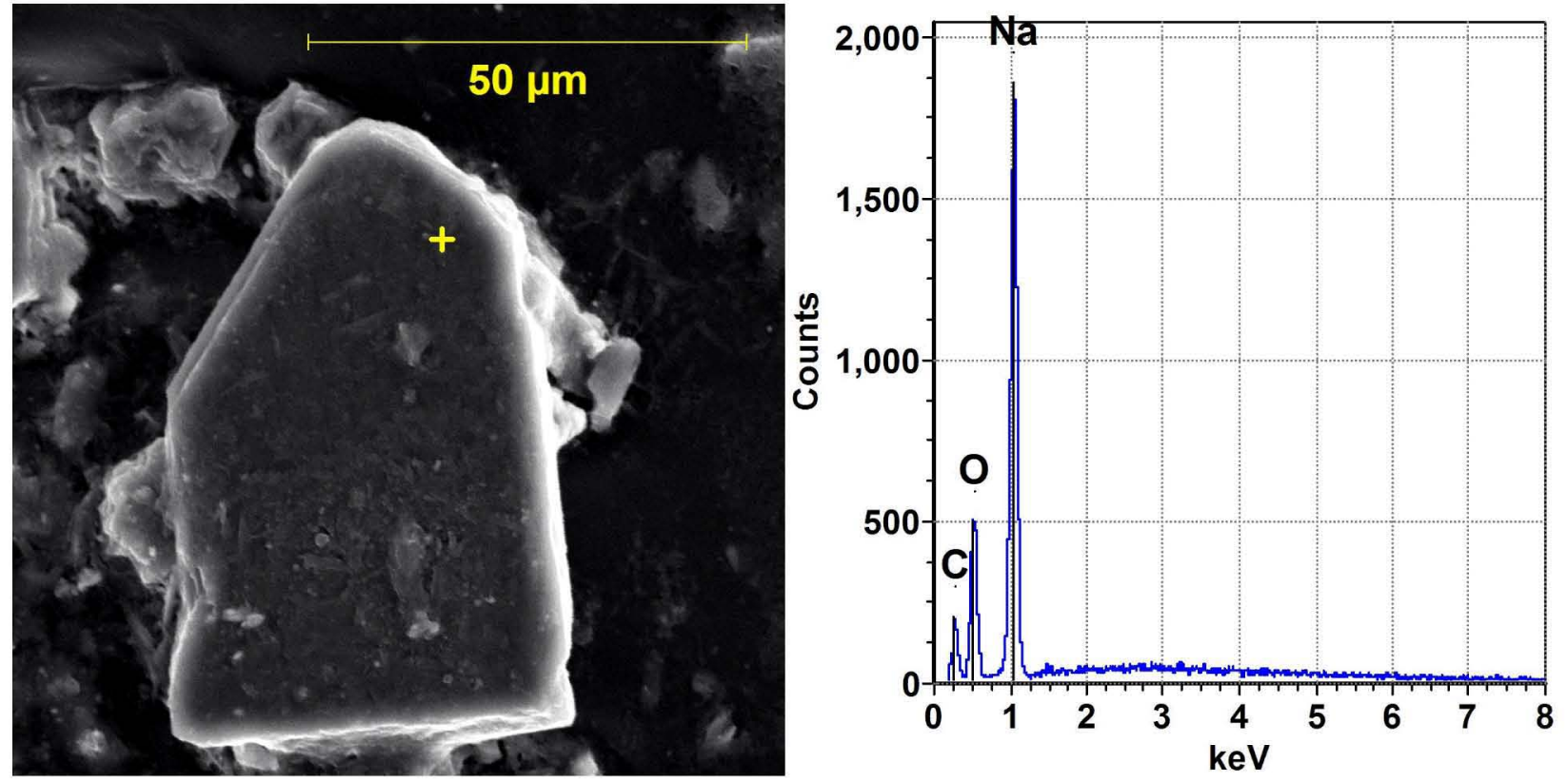
Uranium-rich and iron-rich particulates were readily located by scanning the sample surface in backscatter electron image (BEI) mode. The backscatter electrons reflect better off high atomic weight nuclei, causing them to appear brighter in the BEI image. Uranium-rich material was typically in the form of irregular aggregates of smaller, irregular particulate (Figure 17). The occurrence of sodium with most of the uranium-rich particulate suggests that sodium diuranate or clarkeite are the most likely phase compositions. However, the concentrations of this phase are not high enough (less than several percent) to be identifiable on the XRD patterns.

Figure 17. Sample S12R000491. Backscatter Electron Image of Uranium-Rich Aggregate (Left) with Secondary Electron Image of Same Area (Center) and Energy Dispersive X-Ray Spectrometer Spectrum from Area Marked with + (Right).
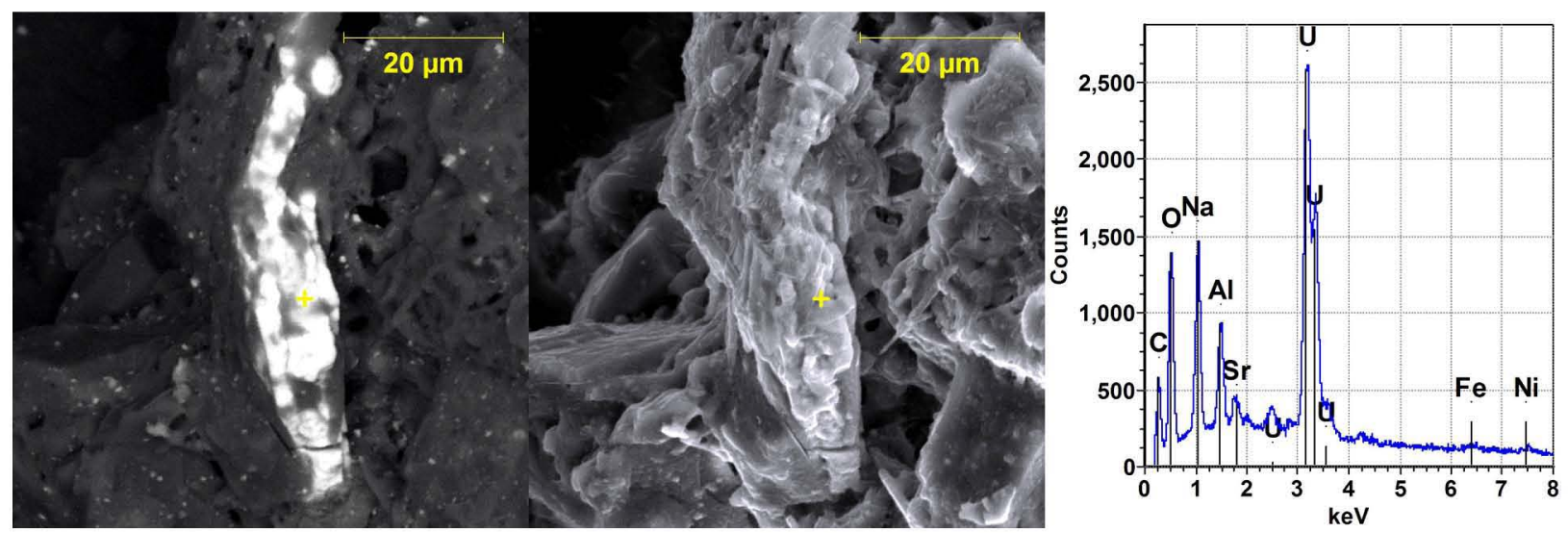

Iron-rich particulate is also readily found in BEI (Figure 18). It occurs as irregular masses and has a variable composition with nickel, manganese, lead, and other elements often included

Figure 18. Sample S12R000491. Backscatter Electron Image of Iron-Rich Aggregate (Left) with Secondary Electron Image of Same Area (Center) and Energy Dispersive X-Ray Spectrometer Spectrum from Area Marked with + (Right).
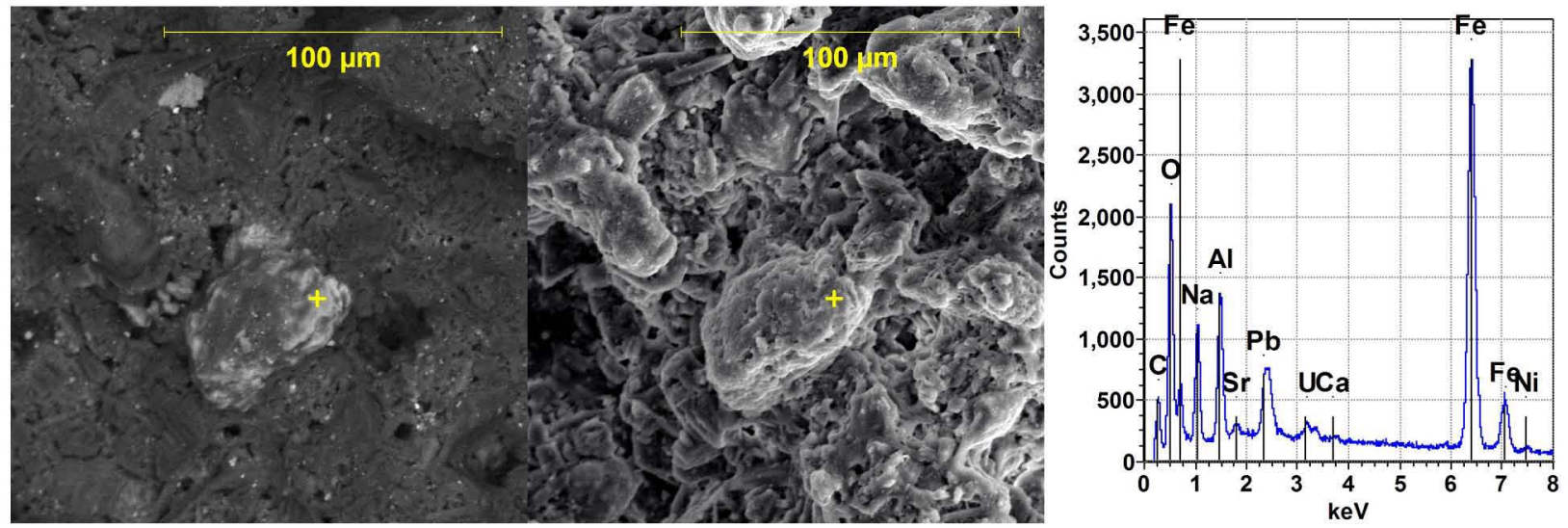

An intriguing occurrence of two strontium-bearing phases was observed in S12R000491 and $\mathrm{S} 12 \mathrm{R} 000492$. The first of these, found only in S12R000491, is a sodium-aluminum-strontium 
bearing phase that was seen as an unusual crystal (Figure 19) and as a more irregular mass (Figure 20). The crystal takes the form of a rhombic dodecahedron.

Figure 19. Sample S12R000491. Backscatter Electron Image of Sodium-AluminumStrontium-Rich Crystal (Upper Left) with Secondary Electron Image of Same Crystal (Upper Right) and Energy Dispersive X-Ray Spectrometer Spectra from Area Marked with +1 (lower Left) and +2 (Lower Right).
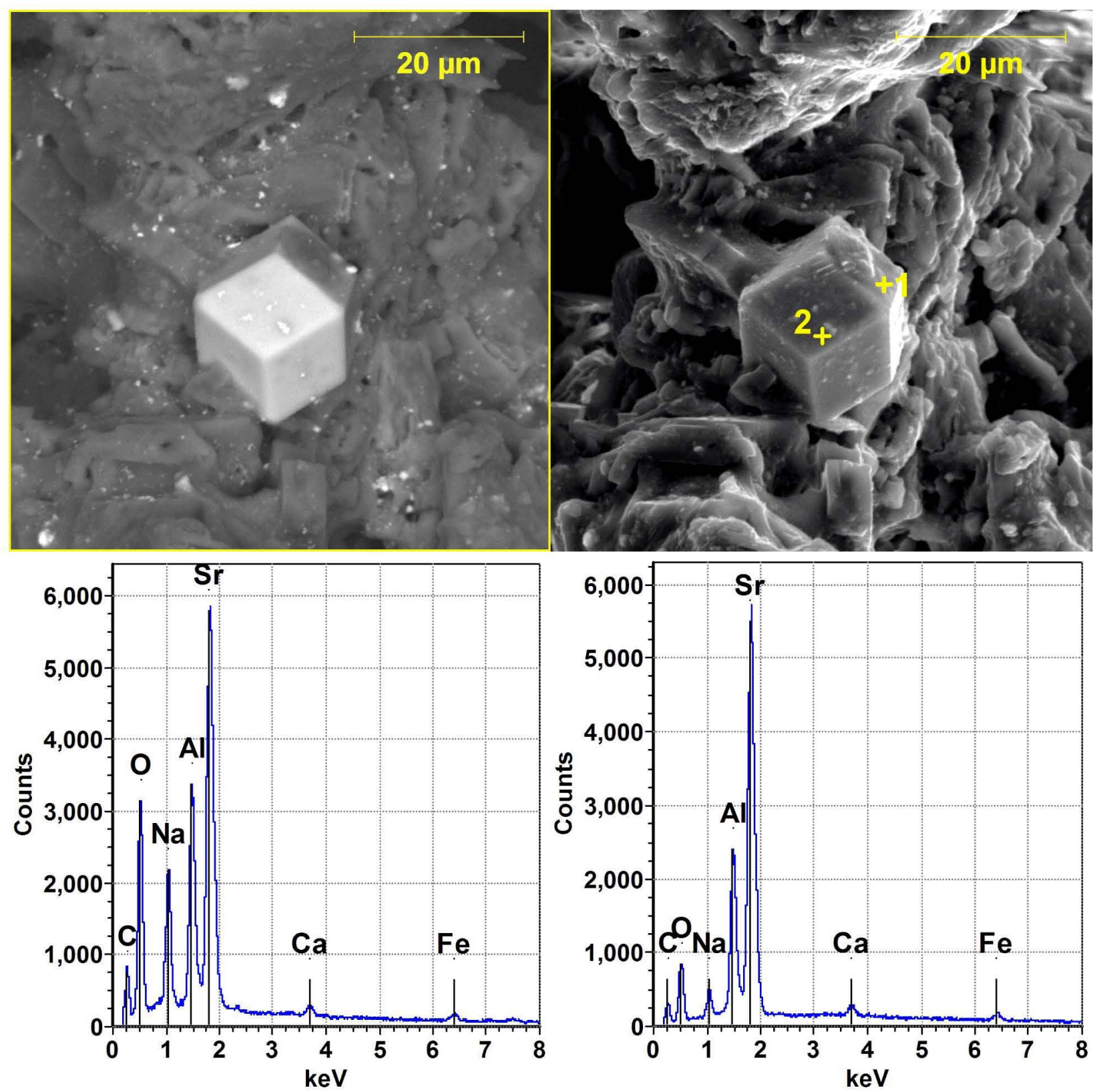
Figure 20. Sample S12R000491. Backscatter Electron Image of Sodium-AluminumStrontium-Rich Irregular Crystal (Left) with Secondary Electron Image of Same Crystal (Center) and Energy Dispersive X-Ray Spectrometer Spectrum from Area Marked with + (Right).
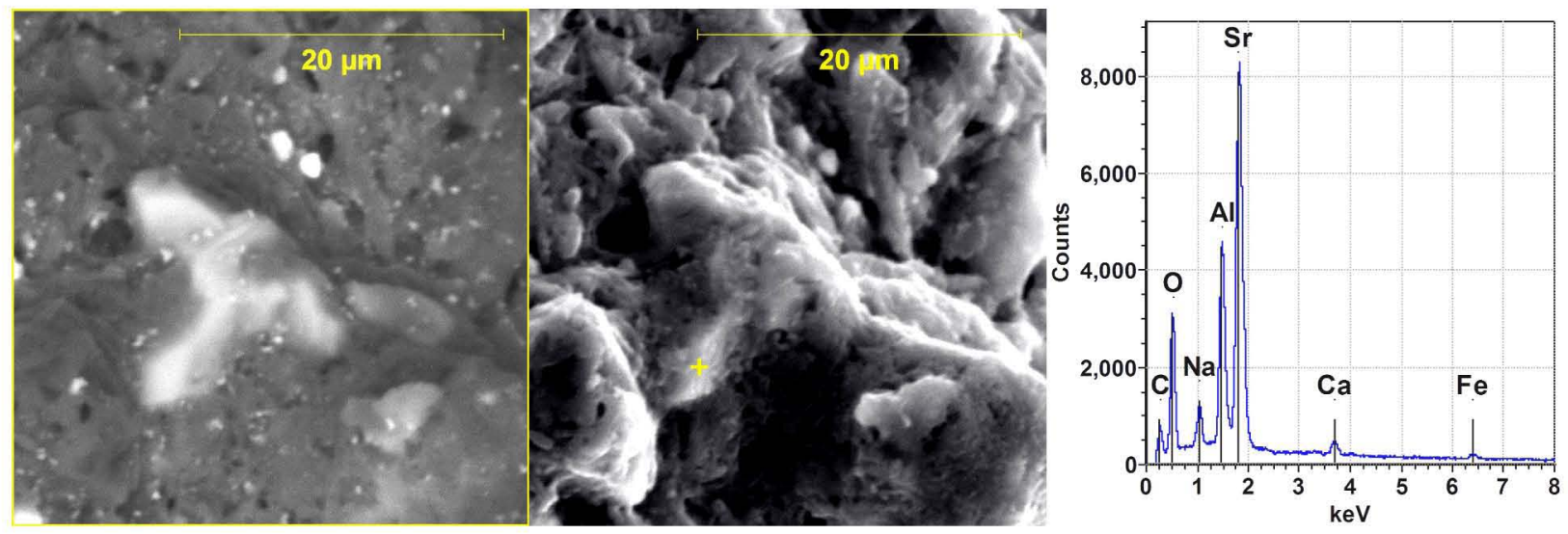

The second strontium-bearing particle type was found only in S12R000492. It is a strontiumrich phase with traces of calcium, aluminum, and sodium that could derive from the surrounding particulate. It was found as a single particle only (Figure 21). Therefore its significance is difficult to determine.

In assessing EDS spectra, care must be exercised with certain elements to avoid misidentifying them due to overlapping, interfering peaks. A minor interference of the silicon Ka peak with the strontium L $\alpha$ peak is readily discriminated because there is a 6-channel $(0.06 \mathrm{keV})$ difference between the two peak positions. As the lower right spectrum in Figure 21 illustrates, confirmation of the strontium identification can be obtained from the $\mathrm{K}$ lines between 14 and $16 \mathrm{keV}$.

However, an interesting lesson in interferences and contamination was presented in the S12R000492 specimen due to the particle shown in Figure 22. Here, a large particle with high BEI intensity (Figure 22, left) was initially considered to show the strontium Ka peak in the EDS spectrum (Figure 22, center). However, the large peak was shifted three channels to the left $(0.03 \mathrm{keV})$, and the smaller peak at about $1.3 \mathrm{keV}$ could not be attributed to strontium. The expanded $\mathrm{X}$ scale in the spectrum to the right shows that the correct identification of the chemical element responsible for the X-ray spectrum is tungsten. The source of this tungsten, with an accompanying carbon peak but no oxygen, is certainly tungsten carbide. This is not tank material! Rather, it is a particle of tungsten carbide from the single sample shielded carriers used at the 222-S Laboratory. 
Figure 21. Sample S12R000492. Secondary Electron Image of Strontium-Rich Irregular Crystal (Left) with Backscatter Electron Image of Area in Yellow Box (Middle) and Energy

Dispersive X-Ray Spectrometer Spectra from Area Marked with + in the Middle Image (Right, $X$ and $Y$ scales of the EDS spectruim are expanded).
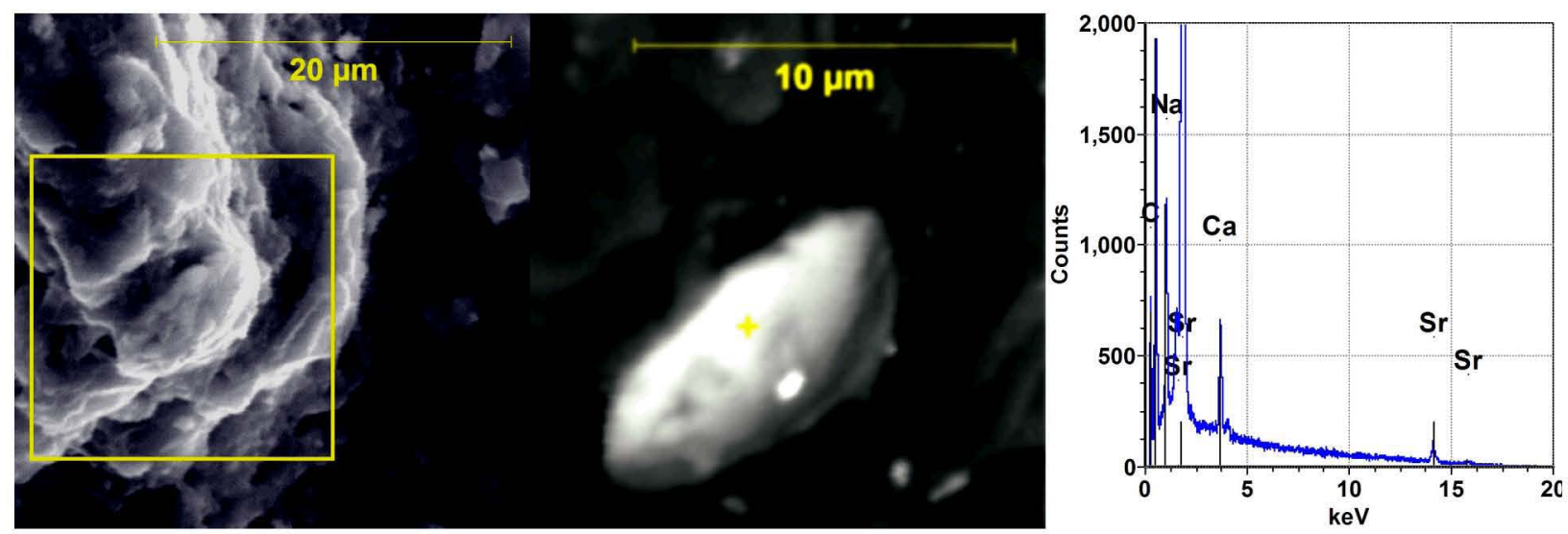
Figure 22. Sample S12R000492. Backscatter Electron Image of Apparent Strontium-Rich Particle (Left). Energy Dispersive X-Ray Spectrometer Spectrum (From Area Marked with +) Could be Confused with Strontium (Center). Actual Element Responsible is Tungsten.
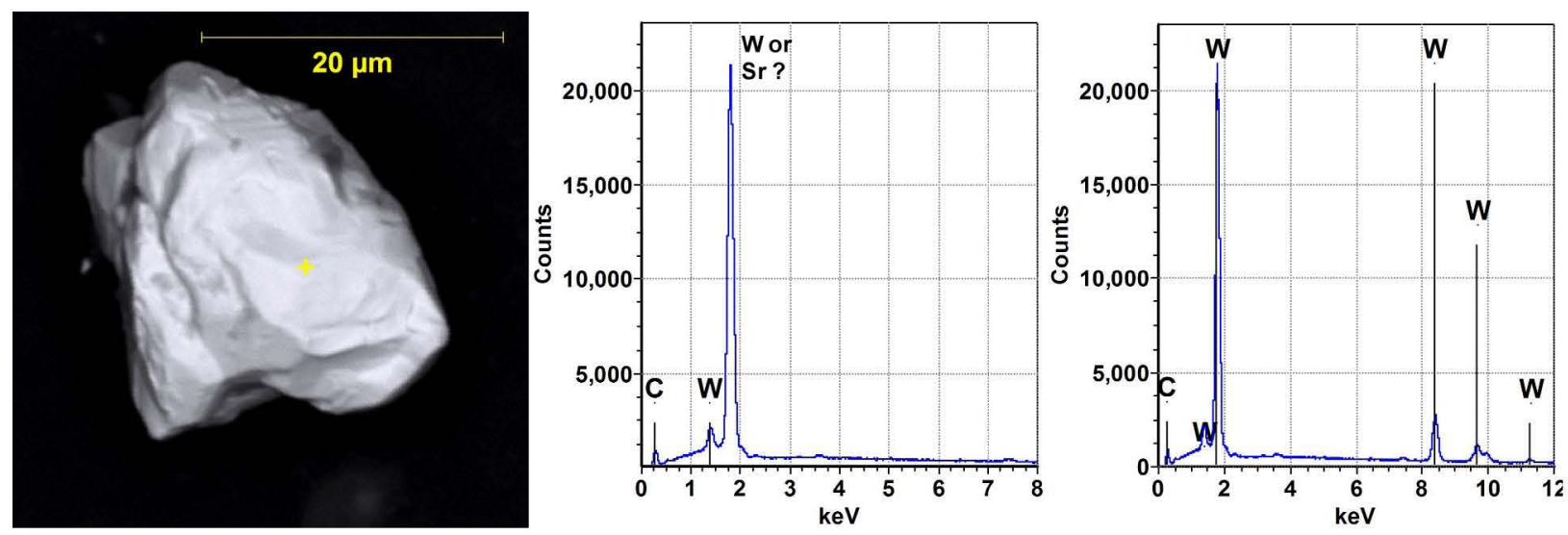

\section{CHARACTERIZATION OF C-108 POST-RETRIEVAL RESIDUAL COMPOSITES}

The composite samples, S12R000494 (brown particulate composite) and S12R000495 (grab sample composite) showed the same crystalline components as the coarse grains. However, S12R000494 showed a lower overall crystallinity, indicating that the darker material is largely amorphous. In addition, natrophosphate appears to make up a larger portion of the crystalline material than it did in the "chunks."

\subsection{X-RAY DIFFRACTION}

Composite Samples S12R000494 and S12R000495 are similar in crystalline composition, however, the crystalline species present in Sample S12R000494 appear to be significantly lower in concentration than in Sample S12R000495 based on observed intensity counts. The sample compositions reported below are relative amounts based upon all the crystalline species present in each individual sample. Refer to laboratory notebook HNF-N-105-1, pages 121-123 for test information and specifics on each individual sample.

S12R000494 (8C-12-CompBrown). Sample S12R000494 (8C-12-CompBrown) appeared to be a wet, dark reddish-brown homogeneous sludge, and once prepared/dried appeared to be homogeneous reddish-brown fine solids. The major crystalline phases of the sample were identified as gibbsite $\left[\mathrm{Al}(\mathrm{OH})_{3}\right]$, thermonatrite $\left[\mathrm{Na}_{2} \mathrm{CO}_{3} \cdot \mathrm{H}_{2} \mathrm{O}\right]$, and natrophosphate $\left[\mathrm{Na} 7 \mathrm{~F}\left(\mathrm{PO}_{4}\right)_{2} \cdot 19 \mathrm{H}_{2} \mathrm{O}\right]$. Overall peak intensity is low, indicating that a substantial portion of the solids are non-crystalline amorphous particulate. 
Chemical Name

Aluminum Hydroxide

Sodium Carbonate Monohydrate

Sodium Fluoride Phosphate Hydrate
Mineral Name

Gibbsite

Thermonatrite

Natrophosphate

\begin{tabular}{lr} 
Formula & $\sim$ Rel. Amount \\
\cline { 2 - 3 }$(\mathrm{OH})_{3}$ & Major \\
$\mathrm{Na}_{2} \mathrm{CO}_{3} \cdot \mathrm{H}_{2} \mathrm{O}$ & Major \\
$\mathrm{Na}_{7} \mathrm{~F}\left(\mathrm{PO}_{4}\right)_{2} \bullet 19 \mathrm{H}_{2} \mathrm{O}$ & Major
\end{tabular}

Figure 23. X-Ray Diffraction Pattern, Sample S12R000494 Brown Composite.

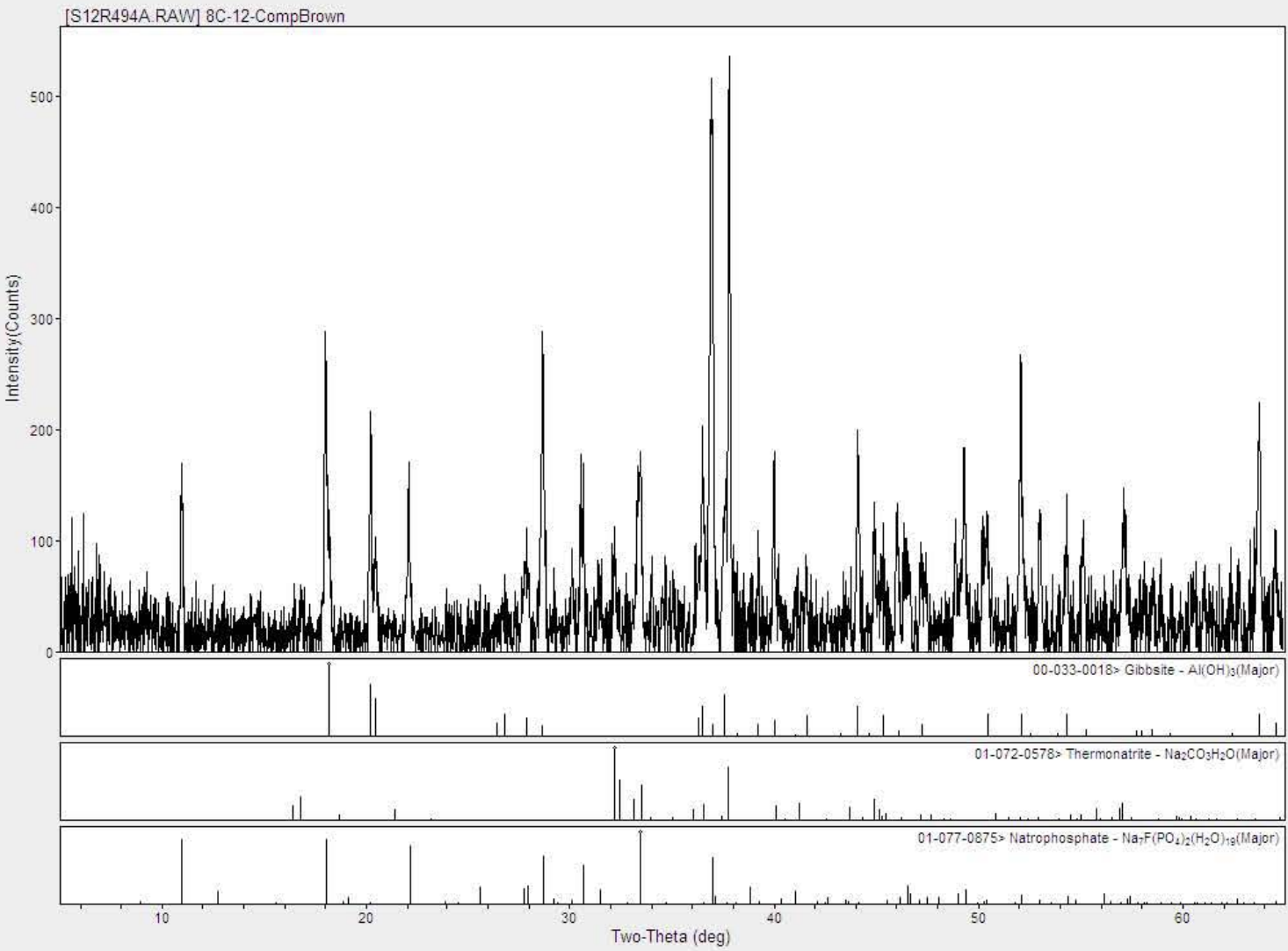

.2225 Laboraton

S12R000495 (8C-12-TankComp). Sample S12R000495 (8C-12-TankComp) appeared to be a wet, dark reddish-brown homogeneous sludge, and once prepared/dried appeared to be homogeneous light reddish-brown fine solids. The major crystalline phases of the sample were identified as gibbsite $\left[\mathrm{Al}(\mathrm{OH})_{3}\right]$, thermonatrite $\left[\mathrm{Na}_{2} \mathrm{CO}_{3} \cdot \mathrm{H}_{2} \mathrm{O}\right]$, and natrophosphate $\left[\mathrm{Na}_{7} \mathrm{~F}\left(\mathrm{PO}_{4}\right)_{2} \bullet 19 \mathrm{H}_{2} \mathrm{O}\right]$.

Chemical Name

Aluminum Hydroxide

Sodium Carbonate Monohydrate

Sodium Fluoride Phosphate Hydrate
Mineral Name

Gibbsite

Thermonatrite

Natrophosphate
Formula

$\overline{\mathrm{Al}(\mathrm{OH})_{3}}$

$\mathrm{Na}_{2} \mathrm{CO}_{3} \cdot \mathrm{H}_{2} \mathrm{O}$

$\mathrm{Na}_{7} \mathrm{~F}\left(\mathrm{PO}_{4}\right)_{2} \bullet 19 \mathrm{H}_{2} \mathrm{O}$
Rel. Amount

Major

Major

Major 
Figure 24. X-Ray Diffraction Pattern, Sample S12R000495 Grab Sample Composite.

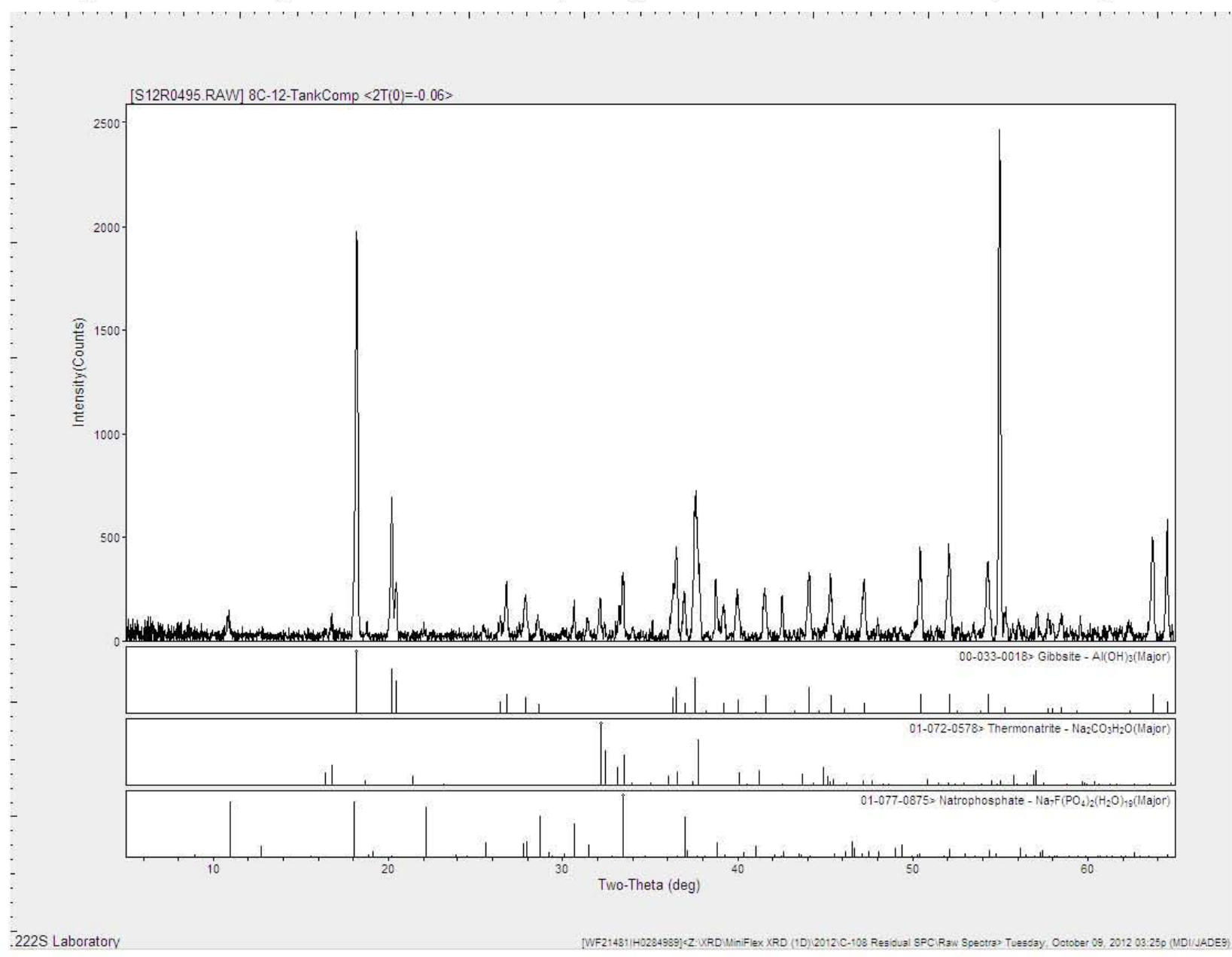

\subsection{POLARIZED LIGHT MICROSCOPY}

S12R000494 (8C-12-CompBrown). Reddish-colored dust causes a highly opaque background on the slides (Figure 25); visible crystals are mostly broken gibbsite and sodium carbonate (up to $20 \mu \mathrm{m}$ diameter). Refer to laboratory notebook HNF-N-395-1, pages 113-114, for test information and specifics on the individual samples. 
Figure 25. Polarized Light Microscopy Image of S12R000494 in 1.55 Oil, Crossed Polarizers, Red I Compensator Plate.

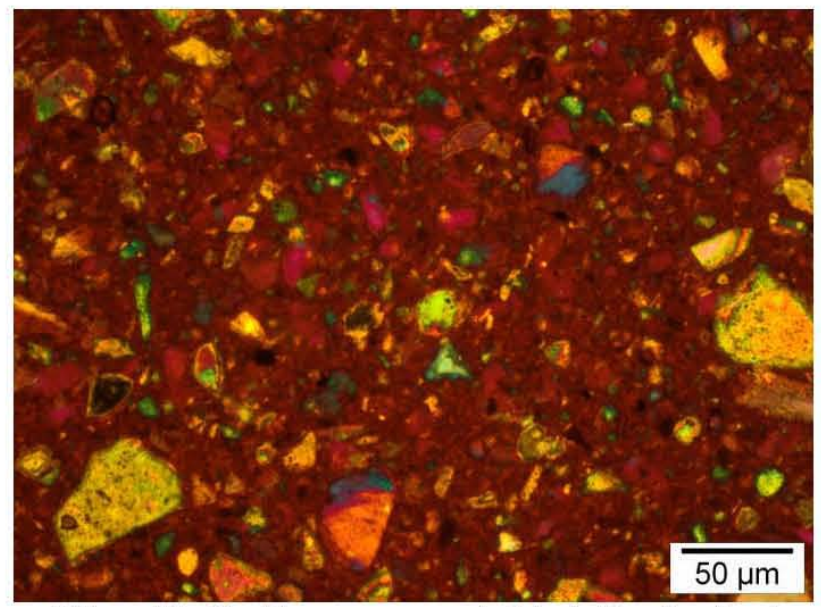

(40x, crP + , Red I comp., mounted in 1.55 refractive)

S12R000495 (8C-12-TankComp). Sample does not contain the reddish dust and shows partially dissolved gibbsite and broken pieces of carbonate. Some natrophosphate is also visible (Figure 26).

Figure 26. Polarized Light Microscopy Images of S12R000495 in 1.55 oil, Uncrossed Polarizers (Left) Crossed Polarizers, Red I Compensator Plate (Right).

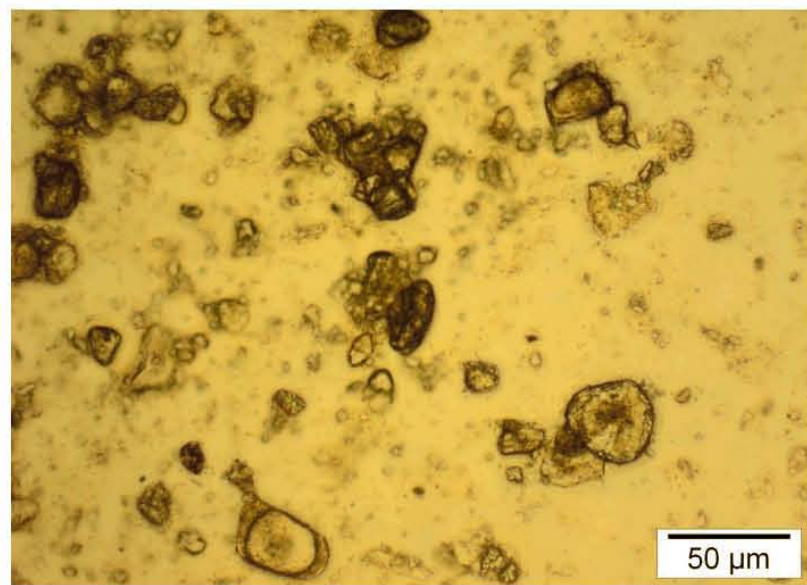

(40x, uncrP, mounted in 1.55 refractive)

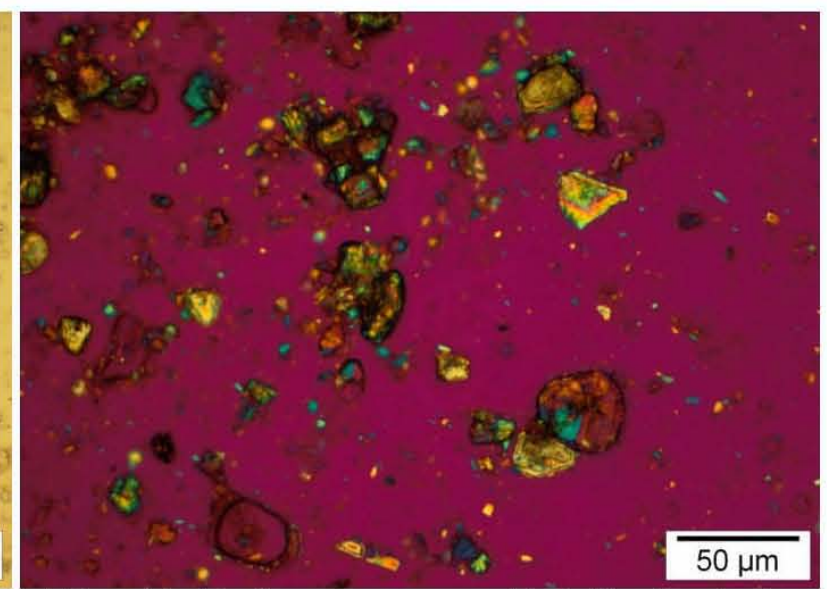

(40x, crP+, Red I comp., mounted in 1.55 refractive)

\subsection{SCANNING ELECTRON MICROSCOPY}

The SEM specimens of the composite samples showed the same mixture of thermonatrite, gibbsite, natrophosphate, and uranium-rich particulate as the "chunk" samples. Figure 27 and Figure 28 show a field view and the area EDS scan from the SEM specimens of S12R000494 and S12R000495, respectively. These spectra are similar to those obtained from the coarse pieces (Figures 9, 10, and 11). However, the brown composite sample, S12R000494 shows 
slightly higher iron, nickel, uranium, and calcium than the coarse pieces or the grab sample composite. The iron, nickel, and uranium, along with some sodium and aluminum, appear to make up the composition of the amorphous, fine-grained material (Figure 29). Test information and specifics on each individual sample are found in HNF-N-832-1, pages 177-178.

Figure 27. Sample S12R000494. Field View and Energy Dispersive X-Ray Spectrometer Spectrum from Area inside Yellow Box.
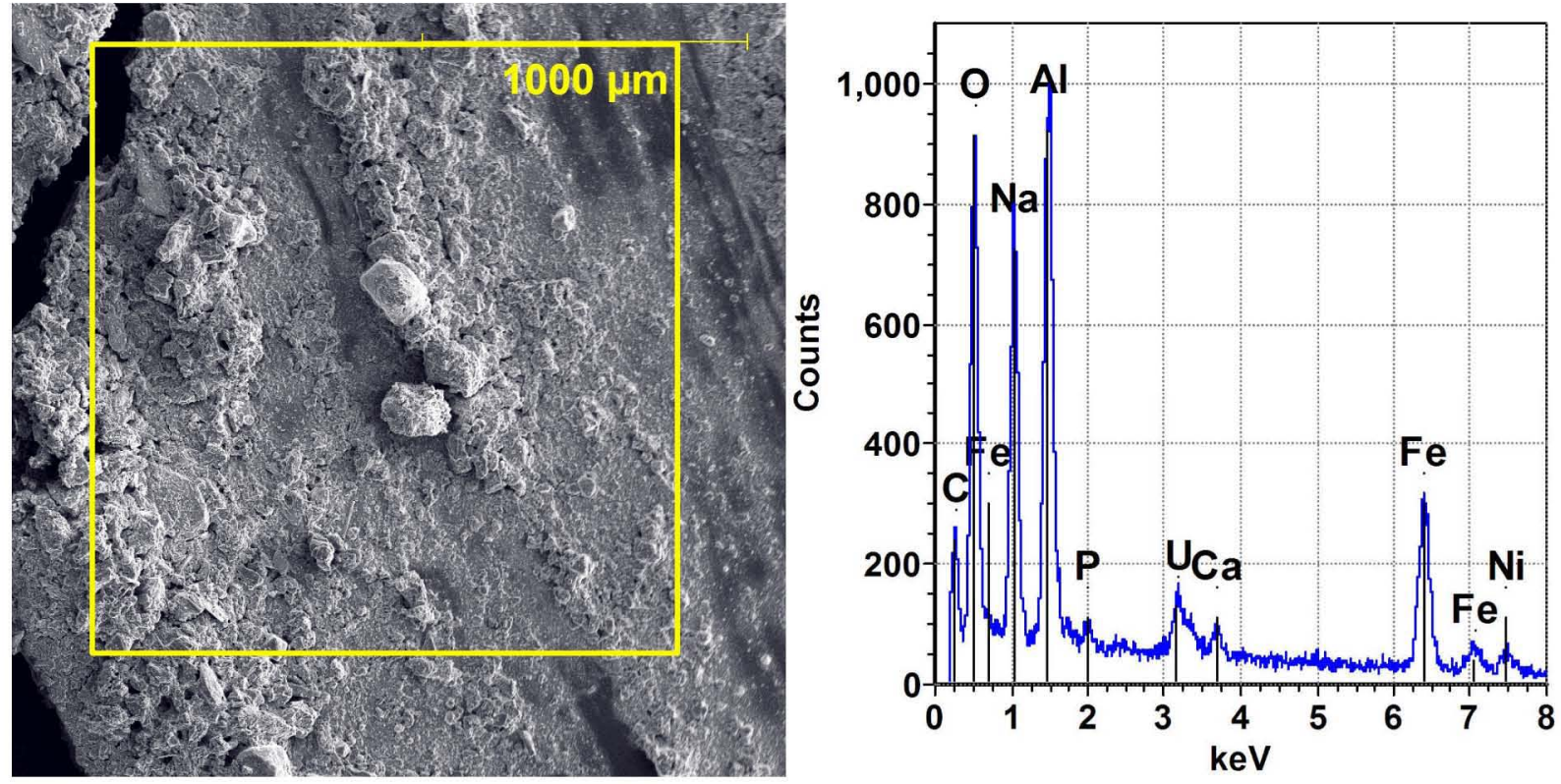

Figure 28. Sample S12R000495. Field View and Energy Dispersive X-Ray Spectrometer Spectrum from Area Inside Yellow Box.
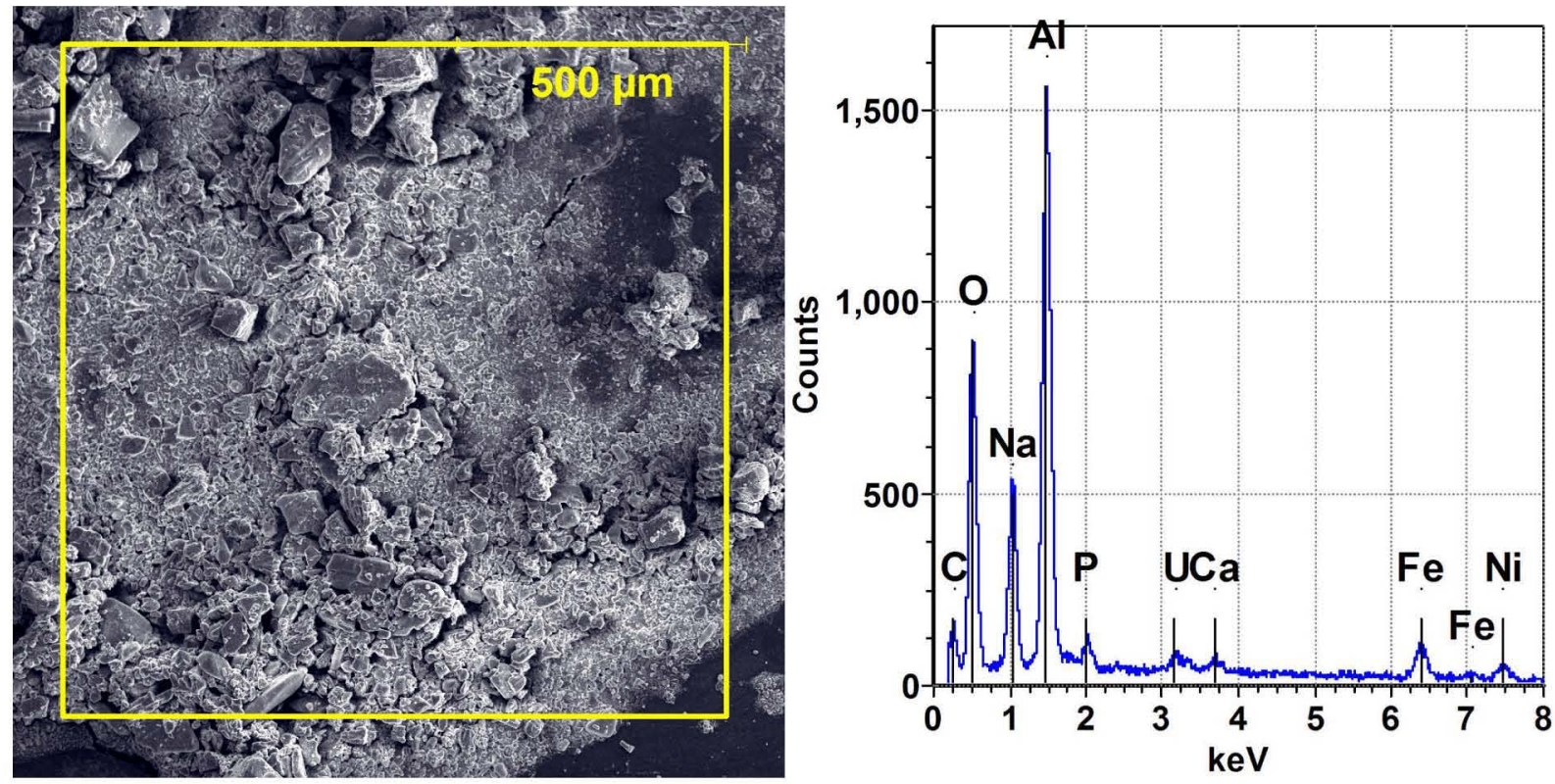
Figure 29. Sample S12R000495. Backscatter Electron Image Close up of Amorphous Material (Left) with Energy Dispersive X-Ray Spectrometer Spectrum from Area Marked with a + to the Right.
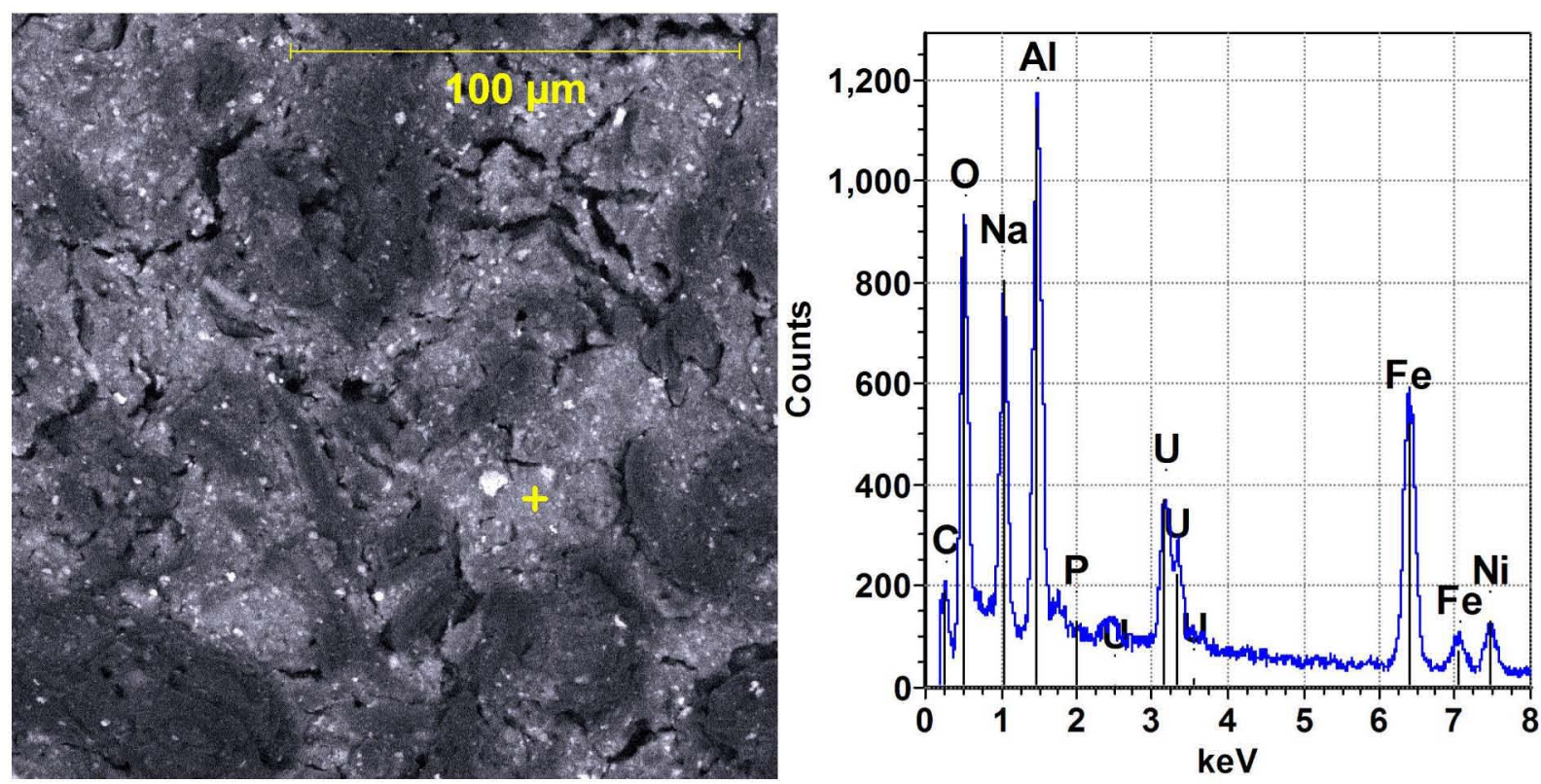

\section{SUMMARY}

The samples in this report were derived from the grab samples taken from the residual material after the solids removal in tank $\mathrm{C}-108$. The difference in mineralogical composition is minor between the three different samples, despite their difference in appearance. All samples contained gibbsite (aluminum hydroxide), thermonatrite (sodium carbonate), and natrophosphate (sodium fluoride phosphate). These three components appear in different stages of dissolution with natrophosphate being predominantly in the fine grained fraction, whereas thermonatrite was found as $\sim 50 \mu \mathrm{m}$ undissolved particles with no pitting. Gibbsite was found as large particles, but with signs of etching and coating.

Additional phases found contained the expected metal associations of $\mathrm{Ni}, \mathrm{Sr}, \mathrm{Fe}$, and $\mathrm{U}$. All of them were identified by SEM/EDS and are either in crystalline form but too small in amount to be detected by XRD, or are amorphous material. This includes a phase not previously observed in Hanford tank waste containing sodium, aluminum, and strontium, which crystallized as a rhombic dodecahedron.

\section{REFERENCES}

ATS-LT-161-100, "222-S Laboratory Sample Preparation and Operating Procedure for Scanning Electron Microscopes," Rev. F-0, Washington River Protection Solutions LLC, Richland, Washington. 
ATS-LT-507-101, “222-S Laboratory X-Ray Diffractometry (XRD),” Rev. I-0, Washington River Protection Solutions LLC, Richland, Washington.

ATS-LT-519-107, "222-S Laboratory Polarized Light Microscopy," Rev. F-1, Washington River Protection Solutions LLC, Richland, Washington.

HNF-N-105-1, "Rigaku ${ }^{\circledR}$ MiniFlex X-Ray Diffractometer,” pp. 121-123, 222-S Laboratory, Washington River Protection Solutions LLC, Richland, Washington.

HNF-N-395-1, "Polarized Light Microscopy Sample Log”, pp. 113-114, 222-S Laboratory, Washington River Protection Solutions LLC, Richland, Washington

HNF-N-832-1, "PSEM Instrument Notebook," pp. 177-178, 222-S Laboratory, Washington River Protection Solutions LLC, Richland, Washington.

RPP-PLAN-52471, 2012, Sampling and Analysis Plan for Residual Waste Solids in Tank 241-C-108, Rev. 00, Washington River Protection Solutions LLC, Richland, Washington.

RPP-RPT-54006, 2012, Final Report for Tank 241-C-108 Residual Solid Samples, Rev. 00A, Washington River Protection Solutions LLC, Richland, Washington. 


\section{Electronically Approved by:}

UserName: Cooke, Gary (h0410221)

Title: APD Chemist

Date: Monday, 29 April 2013, 09:02 AM Pacific Time

Meaning: Approved by the author or delegate

UserName: Pestovich, John (h0284989)

Title:

Date: Tuesday, 30 April 2013, 02:29 PM Pacific Time

Meaning: Additional approval obtained

UserName: Nguyen, Duc (h0051515)

Title: Flowsheet and Process Models

Date: Tuesday, 14 May 2013, 10:15 AM Pacific Time

Meaning: Approved by the customer or delegate

UserName: Greenough, Keith (h0068375)

Title: Laboratory Facilities

Date: Wednesday, 15 May 2013, 04:43 PM Pacific Time

Meaning: Approved by the Facility Manager or delegate

UserName: Seidel, Cary (h0009079)

Title: APD Manager

Date: Tuesday, 21 May 2013, 08:01 AM Pacific Time

Meaning: Approved by the Group Manager or delegate 


\section{DISTRIBUTION SHEET}

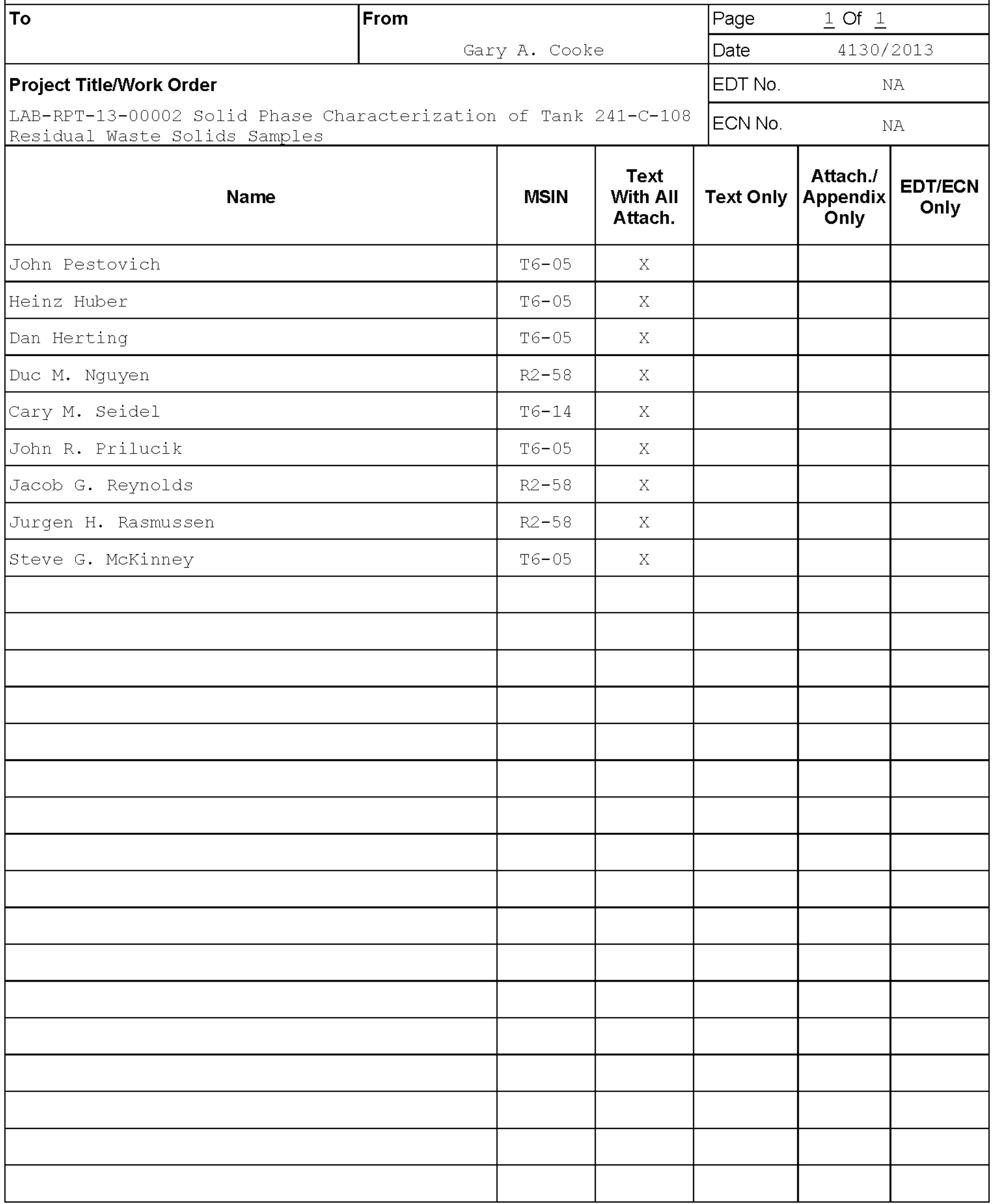

